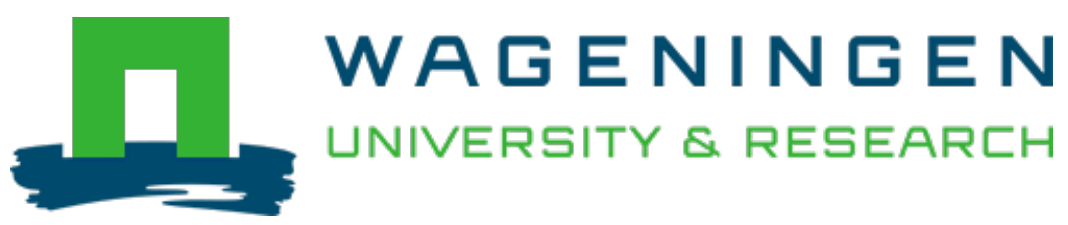

\author{
Mung Bean: Technological and Nutritional Potential \\ Critical Reviews in Food Science and Nutrition \\ Dahiya, P.K.; Linnemann, A.R.; Boekel, M.A.J.S.; Khetarpaul, N.; Grewal, R.B. et al \\ https://doi.org/10.1080/10408398.2012.671202
}

This publication is made publicly available in the institutional repository of Wageningen University and Research, under the terms of article $25 \mathrm{fa}$ of the Dutch Copyright Act, also known as the Amendment Taverne. This has been done with explicit consent by the author.

Article $25 \mathrm{fa}$ states that the author of a short scientific work funded either wholly or partially by Dutch public funds is entitled to make that work publicly available for no consideration following a reasonable period of time after the work was first published, provided that clear reference is made to the source of the first publication of the work.

This publication is distributed under The Association of Universities in the Netherlands (VSNU) 'Article $25 \mathrm{fa}$ implementation' project. In this project research outputs of researchers employed by Dutch Universities that comply with the legal requirements of Article $25 \mathrm{fa}$ of the Dutch Copyright Act are distributed online and free of cost or other barriers in institutional repositories. Research outputs are distributed six months after their first online publication in the original published version and with proper attribution to the source of the original publication.

You are permitted to download and use the publication for personal purposes. All rights remain with the author(s) and / or copyright owner(s) of this work. Any use of the publication or parts of it other than authorised under article $25 \mathrm{fa}$ of the Dutch Copyright act is prohibited. Wageningen University \& Research and the author(s) of this publication shall not be held responsible or liable for any damages resulting from your (re)use of this publication.

For questions regarding the public availability of this publication please contact openscience.library@,wur.nl 


\title{
Mung Bean: Technological and Nutritional Potential
}

\author{
P. K. DAHIYA, ${ }^{1,2,3,4}$ A. R. LINNEMANN, ${ }^{3}$ M. A. J. S. VAN BOEKEL, ${ }^{3}$ \\ N. KHETARPAUL, ${ }^{1}$ R. B. GREWAL, ${ }^{1}$ and M. J. R. NOUT ${ }^{4}$ \\ ${ }^{1}$ Centre of Food Science and Technology, CCS Haryana Agricultural University, Hisar, Haryana, India \\ ${ }^{2}$ Department of Foods and Nutrition, CCS Haryana Agricultural University, Hisar, Haryana, India \\ ${ }^{3}$ Food Quality and Design, Wageningen University, Wageningen, the Netherlands \\ ${ }^{4}$ Laboratory of Food Microbiology, Wageningen University, Wageningen, the Netherlands
}

\begin{abstract}
Mung bean (Vigna radiata (L.) R. Wilczek) has been intensively researched; scattered data are available on various properties. Data on physical, chemical, food processing, and nutritional properties were collected for whole mung bean grains and reviewed to assess the crop's potential as food and to set research priorities. Results show that mung bean is a rich source of protein $(14.6-33.0 \mathrm{~g} / 100 \mathrm{~g}$ ) and iron $(5.9-7.6 \mathrm{mg} / 100 \mathrm{~g})$. Grain color is correlated with compounds like polyphenols and carotenoids, while grain hardness is associated with fiber content. Physical properties like grain dimensions, sphericity, porosity, bulk, and true density are related to moisture content. Anti-nutrients are phytic acid, tannins, hemagglutinins, and polyphenols. Reported nutrient contents vary greatly, the causes of which are not well understood. Grain size and color have been associated with different regions and were used by plant breeders for selection purposes. Analytical methods require more accuracy and precision to distinguish biological variation from analytical variation. Research on nutrient digestibility, food processing properties, and bioavailability is needed. Furthermore, the effects of storage and processing on nutrients and food processing properties are required to enable optimization of processing steps, for better mung bean food quality and process efficiency.
\end{abstract}

Keywords Nutrients, anti-nutrients, minerals, fatty acids, amino acids, physical properties

\section{INTRODUCTION}

Mung bean or green gram (Vigna radiata (L.) R. Wilczek) has been cultivated in India since prehistoric times and is believed to be a native crop of India (Vavilov, 1926). It is cultivated throughout Southern and Eastern Asia, Central Africa, some parts of China, South and North America and Australia, particularly for its protein-rich grains. Mung bean is a warm seasonal annual legume, grown mostly as a rotational crop with cereals like wheat and rice. Mung bean plants are erect with branches carrying pods in clusters near the top of the plant. Pods contain $8-15$ seed grains. The grains are green or brown colored and globose in shape with a flat hilum. The crop's main advantages are that, as a legume, it does not require fertilization for nitrogen (Murakami et al., 1991), and that it has a short growth cycle (75-90 days), requires little water and fits easily into crop rotations with cereals. It grows well under most adverse arid and semiarid conditions.

Address correspondence to A. R. Linnemann, Product Design and Quality Management Group, P. O. Box 81296700 EV Wageningen, the Netherlands. E-mail: anita.linnemann@wur.nl
Mung bean is considered a good source of protein (Engel, 1978). Its different food products such as dhals (i.e., thick stews from dehulled and split grains), sweets, snacks, and savory foods have evolved and became popular in the Indian subcontinent (Adsule et al., 1986; Singh et al., 1988), whereas products like cake, sprouts, noodles, and soups evolved in oriental countries like China (Cheng et al., 1988; Singh and Singh, 1992), the Philippines (Rosario, 1991) as well as in Iran (Amirshahi, 1978) and Thailand (Prabhavat, 1990).

Biochemical analyses in previously published studies reveal that mung bean and its processed products are rich in nutrients. Chemistry and technology of mung bean have been reviewed previously by Adsule et al. (1986), who provided substantial information on the nutritional aspects, but only gave limited information on processing of mung bean. Some publications also reviewed mung bean food products (Adsule et al., 1986; Prabhavat, 1990; Rosario, 1991; Singh and Singh, 1992). However, these reviews are dated and do not deal in detail with the physical and food processing properties of mung bean grains, or other new developments in mung bean chemistry. Knowledge about the effects of food processing and physical characteristics 
is essential to enable standardization and quality assurance of foods prepared by different processing methods. The present review investigates the physical, chemical, food processing, and nutritional properties of raw mung bean grain based on literature data and critically evaluates the similarities and divergences of the values in relation to the research methods used. Although the chemistry of raw grains does not represent the nutrient content of mung bean as consumed, the data establish the potential of stored nutritional composition of the grain. For each component, the reported values are, as much as possible, converted into the same unit, and their average, minimum, and maximum values are calculated and reported in tables. Finally, further research needs are identified for strengthening the knowledge base of this important food grain.

For the purpose of this review, we searched all scientific publication sources relating to chemistry, processing, and consumption of mung bean. We focused, however, on the more recent literature data. We included four data sources from the period 1926-1960, 1 source from the seventies, 23 sources from the eighties, 36 from the nineties, 29 from the period 1991-2000, whereas the period 2001 till present yielded 50 relevant publications.

\section{A. PHYSICAL AND ENGINEERING PROPERTIES}

Knowledge of physical and engineering properties is essential for designing equipment for processing, transportation, sorting, separation, and storage. Physical properties of mung bean grains and their relation with its chemical composition, particularly with moisture content, have been studied (Nimkar and Chattopadhyay, 2001; Mangaraj et al., 2005; Yildiz, 2005; Unal et al., 2008). The relevant physical properties of mung bean grains include shape, size, mass, volume, bulk density, true density, porosity, static friction against different surfaces, rupture strength, angle of repose, and terminal velocity (Table 1). Volume, density, and porosity are among the parameters that determine the suitability of mung bean grains for processing technologies and affect grain resistance toward air flow in transport and separation unit operations (Unal et al., 2008). Rupture strength of the grains determines the milling behavior and cookability of the grains, as grains with low rupture strength will be easy to handle in flour making and soften easily during cooking. Dimensions of mung bean grains are important for the quality of its derived products, such as texture in the case of sprouts and consistency in the case of dhals. Consumer's appreciation for sprouts may vary with bean varieties of different sizes.

\section{Dimensions and Shape of the Grain}

Physical dimensions of the grain, i.e., length $(L)$, width $(B)$, and thickness $(T)$, are relevant in grading, sorting, sieving, and other postharvest operations. Grain size plays an important role
Table 1 Physical and engineering properties of mung bean

\begin{tabular}{|c|c|c|c|c|}
\hline $\begin{array}{l}\text { Physical and } \\
\text { engineering } \\
\text { properties }\end{array}$ & Average* & Minimum & Maximum & References \\
\hline Length (mm) & 4.9 & 4.2 & 6.2 & $\begin{array}{l}\text { (Nimkar and } \\
\text { Chattopadhyay, 2001; } \\
\text { Mangaraj et al., 2005; } \\
\text { Yildiz, 2005; Unal } \\
\text { et al., 2008) }\end{array}$ \\
\hline Width (mm) & 3.7 & 3.2 & 4.5 & $\begin{array}{l}\text { (Nimkar and } \\
\text { Chattopadhyay, 2001; } \\
\text { Mangaraj et al., 2005; } \\
\text { Yildiz, 2005; Unal } \\
\text { et al., 2008) }\end{array}$ \\
\hline Thickness (mm) & 3.6 & 3.1 & 4.2 & $\begin{array}{l}\text { (Nimkar and } \\
\text { Chattopadhyay, 2001; } \\
\text { Mangaraj et al., 2005; } \\
\text { Yildiz, 2005; Unal } \\
\text { et al., 2008) }\end{array}$ \\
\hline $\begin{array}{l}\text { Geometric mean } \\
\text { diameter }(\mathrm{mm})\end{array}$ & 4.3 & 3.7 & 4.9 & $\begin{array}{l}\text { (Mangaraj et al., 2005; } \\
\text { Yildiz, 2005; Unal } \\
\text { et al., 2008) }\end{array}$ \\
\hline Sphericity & 0.82 & 0.75 & 0.90 & $\begin{array}{l}\text { (Mangaraj et al., 2005; } \\
\text { Yildiz, 2005; Unal } \\
\text { et al., 2008) }\end{array}$ \\
\hline Volume $\left(\mathrm{mm}^{3}\right)$ & 33.2 & 30.4 & 35.0 & $\begin{array}{l}\text { (Yildiz, 2005; Unal } \\
\text { et al., 2008) }\end{array}$ \\
\hline $\begin{array}{l}\text { Thousand seed } \\
\text { weight }(\mathrm{g})\end{array}$ & 35.6 & 7.3 & 60.1 & $\begin{array}{l}\text { (Nimkar and } \\
\text { Chattopadhyay, 2001; } \\
\text { Mangaraj et al., 2005; } \\
\text { Yildiz, 2005; Unal } \\
\text { et al., 2008) }\end{array}$ \\
\hline $\begin{array}{l}\text { Bulk density } \\
\qquad\left(\mathrm{kg} \mathrm{m}^{3}\right)\end{array}$ & 756.81 & 679.1 & 821.3 & $\begin{array}{l}\text { (Nimkar and } \\
\text { Chattopadhyay, 2001; } \\
\text { Yildiz, 2005; Unal } \\
\text { et al., 2008) }\end{array}$ \\
\hline $\begin{array}{l}\text { True density (kg } \\
\mathrm{m}^{3} \text { ) }\end{array}$ & 1335.4 & 1230.0 & 1456.7 & $\begin{array}{l}\text { (Nimkar and } \\
\text { Chattopadhyay, 2001; } \\
\text { Unal et al., 2008) }\end{array}$ \\
\hline Porosity (\%) & 40.8 & 30.4 & 47.1 & $\begin{array}{l}\text { (Nimkar and } \\
\text { Chattopadhyay, 2001; } \\
\text { Yildiz, 2005; Unal } \\
\text { et al., 2008) }\end{array}$ \\
\hline $\begin{array}{l}\text { Terminal velocity } \\
\quad\left(\mathrm{m} \mathrm{s}^{-1}\right)\end{array}$ & 7.5 & 4.9 & 12.1 & $\begin{array}{l}\text { (Nimkar and } \\
\text { Chattopadhyay, 2001; } \\
\text { Yildiz, 2005; Unal } \\
\text { et al., 2008) }\end{array}$ \\
\hline $\begin{array}{l}\text { Angle of repose } \\
\text { (degree) }\end{array}$ & 27.6 & 25.9 & 29.4 & $\begin{array}{l}\text { (Nimkar and } \\
\text { Chattopadhyay, 2001; } \\
\text { Unal et al., 2008) }\end{array}$ \\
\hline $\begin{array}{l}\text { Projected area } \\
\left(\mathrm{mm}^{2}\right)\end{array}$ & 18.4 & 17.5 & 19.3 & (Unal et al., 2008) \\
\hline
\end{tabular}

*Mean value of all collected data.

in selection and distribution of mung bean varieties around the globe, as consumers selected varieties with specific sizes along with other agronomic characteristics (Tomooka et al., 1991; Mangaraj et al., 2005). This has led to three mung bean areas on the basis of seed size, namely the Indian subcontinent with small-seeded mung bean, south-east Asia with largesized mung bean, and east Asia with medium-sized mung been grains (Tomooka et al., 1991). The reported length, width, and 
thickness of the mung bean are given in Table 1. Dimensions of the mung bean grain were measured by analog or digital Vernier calliper (Nimkar and Chattopadhyay, 2001), whereas Yildiz (2005) used a micrometer. Measurements were done at different moisture contents, ranging from 6.7 to $33.4 \% \mathrm{dw}$ (dry weight). From these results, all authors (Nimkar and Chattopadhyay, 2001; Yildiz, 2005; Unal et al., 2008) concluded that length, width, and thickness are a function of moisture content of the grains and that dimensions increase at higher moisture contents with a high correlation coefficient $\left(R^{2}=0.998\right)$. The reported geometric mean diameter $(D)$ was calculated by the equation, $D=(L \times B \times T)^{1 / 3}$. The variation in the dimension may be due to the use of different varieties and can be influenced by sample quality, particularly moisture content. However, use of an analog Vernier calliper or micrometer as tools of analysis seems to have no effect on the calculated values. Length/width ratio of the mung bean ranged from 1.0 to 1.5 , which was used as an indicator of the shape of mung bean (Tomooka, 1991). Grain size is also reported to be correlated with protein content as discussed later in this paper.

Sphericity of the grain is the geometric tolerance of the grain that indicates how much it deviates from a perfectly round sphere. Sphericity $(\phi)$ was calculated by the equation $\phi=D / L$, where $D$ is the geometric mean diameter and $L$ is the length of the grain. Its value is the ratio and thus dimensionless. Higher values of sphericity indicate that the shape of the grain is closer to a sphere. This parameter is important in the movement of the grains during milling, sorting, and dehulling processes and for determination of terminal velocity, the drag coefficient, and the Reynolds number. The sphericity of the mung bean grain decreases nonlinearly with an increase in the moisture content from 6.7 to $18.6 \%\left(R^{2}=0.892\right)$ (Unal et al., 2008) and is comparable to that of cowpea (Yalcin, 2007), millet (Baryeh, 2002), and pea (Yalcin et al., 2007) with values ranging from $0.78-0.80$, $0.79-0.80$, and $0.84-0.85$, respectively.

\section{Grain Color and Appearance}

The color of the mung bean grain is a quality indicator, as consumers select grains of a specific color and reject others. Mung bean grains generally appear green but other colors have also been reported (Paroda and Thomas, 1988). The color of the grain is due to the color of the testa. The cotyledons are generally pale yellow. Colors of mung bean grains may range from dark green, light yellow, light green, deep green, shining green, dull green, golden yellow to mottled yellow (Yousif et al., 2003; Katiyar et al., 2007). Mung bean grains have been divided into five groups on the basis of grain color, i.e., green with glossy seed, dull green, yellow with glossiness and dull luster, black with glossy luster, and brown with dull seed luster by Tomooka et al. (1991), who identified a geographic gradient for mung bean varieties based on grain color. Most of the shiny green mung bean varieties (49\%) are from the Philippines, Vietnam, Thailand, India, Pakistan, and Afghanistan, whereas dull green varieties are mainly from Korea, China, Taiwan, Turkey, and Indonesia. Yellow colored varieties are from Korea, Taiwan, the Philippines, Indonesia, Thailand, and India but account for only $4 \%$ of the studied varieties, whereas brown varieties are mainly from Iran, Iraq, Pakistan, and the Afghan region (Tomooka et al., 1991). The variation in grain color may be due to differences in genetic makeup (Akhtar et al., 1988; Pandey et al., 1989; Bhadra et al., 1991; Chen and Liu, 2001; Yousif et al., 2003; Katiyar et al., 2007) and storage conditions (Yousif et al., 2003). Color of the grains is an important property for varietal identification and acts as a marker for breeding experiments (Chhabra et al., 1990). Dark colored mung bean grains have been reported to contain higher polyphenol levels (Salunkhe et al., 1982; Muhammed et al., 2010), probably due to higher concentrations in the grain testa (Barroga et al., 1985). Yellow mung bean varieties contained higher quantities of seed coat polyphenols than green varieties, which indicate effective removal of polyphenols in yellow varieties by the dehulling process. Difference in color in mung bean varieties is also due to different carotenoid contents as discussed later in the paper. The color of the grain imparts color to certain food products prepared by use of whole mung beans, thus it seems that mung bean varieties that impart odd colors to a product will not be acceptable. Authors reported mung bean colors based on subjective observations; to our knowledge, no author reported the color of mung bean based on instrumental studies.

\section{Grain Hardness}

Hardness is the ability of the grain to resist penetration, breakage, and scratching. Sood et al. (1982) reported grain hardness of nine mung bean varieties to range from 1.9 to $3.8 \mathrm{~kg} / \mathrm{seed}$ with an average of $3.0 \mathrm{~kg} / \mathrm{seed}$, measured using a unspecified hardness tester. Grain hardness has been reported to correlate with grain weight (Humphry et al., 2005) and color of the grains. Felicito and Evelyn Mae (1990) reported that high lignin and silica contents in combination with a compact solid structure can be the reason for the hardness of the seed coat in hard mung bean grains, as well as for their impermeability to water. Mendoza et al. (1988) reported that hardness of mung bean occurs in fresh grains mostly during the dry season and that yellow varieties are more likely to develop hardness. Felicito and Evelyn Mae (1990) reported that hydroxyprolines and pectins are not involved in the hard seed coat phenomenon of mung bean as they did not find hydroxyprolines in the amino acid profile of mung bean and the pectin content of normal and hard grains showed no significant difference. The authors also reported that the thickness of the seed coat of hard seeds was twice that of normal seeds, which may be due to the reported 9-25\% higher fiber content. Various authors (Molina et al., 1974; Werker et al., 1979) have correlated hardness of grains with high concentrations of pectin substances. To our knowledge, no study has been conducted on the effect of storage, maturity, and moisture content on the hardness of mung bean grains. Similarly, no comparative study 
has been done on the grain hardness of the normal, as well as hard-to-cook mung bean grains, which would be important for optimization of the processing conditions.

\section{Volume of the Grain}

Grain volume is a parameter that helps to calculate different other parameters that are important for handling processes. Yildiz (2005) reported a volume of 30 and $35 \mathrm{~mm}^{3}$ for mung bean grains at moisture contents of 6.7 and $18.6 \%$, respectively. The variation in the volume of the mung bean grain is due to its moisture content, which depends on the maturity level of the grain at the time of harvest and postharvest drying.

\section{Grain Weight}

Grain weight is important for different handling processes. It varies within and between grains of different varieties in relation to growing conditions and maturity at harvest as this influences the moisture content. After harvesting, its value may change depending on the storage conditions. Mung bean has relatively small grains in comparison to other commonly used pulses (Nimkar and Chattopadhyay, 2001). The reported thousand seed weights (Table 1) were estimated with moisture contents ranging from 8.4 to $33.4 \% \mathrm{dw}$ by weighing 100 randomly selected grains from the bulk and then calculating the 1000 grain weight. Tomooka (1991) observed a geographic gradient for the distribution of mung bean varieties on the basis of seed weight, as he did for seed color. He noted that small-seeded varieties with a low seed weight were found predominantly in the Indian subcontinent and West Asia, whereas seeds with higher weights were found mainly in south-east Asian countries.

\section{Bulk Density of the Grain}

Mangaraj et al. (2005) and Unal et al. (2008) determined bulk density $\left(\rho_{\mathrm{b}}\right)$ with the help of a 1000-ml measuring cylinder, whereas Yildiz (2005) and Nimkar and Chattopadhyay (2001) used a hectoliter tester. Grain samples were poured in the measuring cylinder and weighed. Bulk density is expressed as the ratio of mass of the sample and its volume (Nimkar and Chattopadhyay, 2001; Mangaraj et al., 2005). The values of bulk density were reported to have a negative linear relationship with the moisture content (MC) of the grain. Unal et al. (2008) reported that the bulk density of the grain bears the following relationship with moisture content with a coefficient of determination of $R^{2}=0.99$ :

$\rho_{\mathrm{b}}=867.3-6.2 \mathrm{MC}$.
According to Nimkar and Chattopadhyay (2001), this relationship is

$\rho_{\mathrm{b}}=843.3-4.2 \mathrm{MC}$.

Unal et al. (2008) reported that the bulk density of mung bean at a moisture content of $14.7 \% \mathrm{dw}$ is larger than that of most pulses, for example, gram and soya bean grain, due to the larger size of these grains as compared to mung bean. To our knowledge, bulk density of whole mung bean flour has not been determined.

\section{Grain (True) Density}

Grain density is the ratio of mass of the grain to its volume. It is different from the bulk density in the fact that true density is the density of a single grain, whereas bulk density is the density of certain amount of grains in a given vessel or container, which also includes the void spaces between the grains. It can be measured either by air or by liquid displacement methods. Water and toluene are the liquids used in the liquid displacement method. Unal et al. (2008) reported that true density shows a positive linear relation with moisture content, whereas Nimkar and Chattopadhyay (2001) found the opposite. These authors reported altogether different correlations, although both used the same toluene displacement method for the determination of true density by calculating the ratio of sample mass to the true volume of particles.

\section{Porosity of the Grain}

Porosity of the bulk of grain is a measure of the void spaces in a material, and is a fraction of the volume of voids over the total volume. Its value depends on the values of true and bulk density. It is important as it influences milling properties, drying rate, breakage susceptibility, and grain hardness. The bulk porosity $(\varepsilon)$ of the mung bean grain was calculated by using mean values of the bulk density and true density in the flowing equation:

$\varepsilon=100\left[1-\left(\rho_{\mathrm{b}} / \rho_{\mathrm{t}}\right)\right]$

where $\rho_{\mathrm{b}}$ and $\rho_{\mathrm{t}}$ are bulk density and true density, respectively. Unal et al. (2008) reported that bulk porosity of mung bean, at a moisture content of $12.6 \% \mathrm{dw},(38.7 \%)$ is smaller than for chick pea $(43.6 \%)$, and pigeon pea (41.7\%). This may be due to the larger sizes of chickpea and pigeon pea grains.

\section{Terminal Velocity of the Grain}

Terminal velocity is an important parameter in aerodynamic and hydrodynamic behavior, and depends on acceleration of gravity and fluid flow. It is important, for instance, when separating chaff and grain. Terminal velocity has a positive linear 
relationship with moisture content of the grain. Nimkar and Chattopadhyay (2001) reported that an increase in terminal velocity with an increase in moisture content is due to the increase in mass of individual grains per unit frontal area facing the air stream during suspension. Moreover, an increase in moisture content also increases the size of the grain, which also affects terminal velocity. Most authors used air column and temperaturetype anemometers to determine the terminal velocity. In this method, grains are positioned on a platform confronting a controlled airflow. By increasing the airflow gradually, the grains start to float to a certain height. The air velocity at this height is measured as terminal velocity.

\section{Coefficient of Static Friction of the Grain}

The coefficient of friction is the degree of interaction between two surfaces. It has a dimensionless value from 0 to 1 , the latter indicating a greater resistance. The coefficient of friction plays its role in transport, storage, and packaging of mung bean grains (Unal et al., 2008), for example, in the construction of silo walls and selection of materials for postharvest cleaning and grading equipment and packaging material. The reported values were assessed at moisture levels of grains ranging from 8.4 to $33 \%$ $\mathrm{dw}$. The coefficient of static friction of mung bean showed a positive linear relationship with moisture content. According to Nimkar and Chattopadhyay (2001), this increase is due to increased adhesion between the grains and the material surface at higher moisture contents. The coefficient of static friction of mung bean is reported to be highest against rubber (from 0.40 to 0.63 ) and least for glass (from 0.32 to 0.35 ). Nimkar and Chattopadhyay (2001) reported that rubber as a surface for sliding offered maximum friction followed by galvanized iron, fiber board, stainless steel, aluminum, and glass. To determine the coefficient of static friction, the authors placed a plastic cylinder of $100 \mathrm{~mm}$ diameter and $50 \mathrm{~mm}$ height filled with sample on an adjustable tilting plate. The cylinder was raised slightly so as not to touch the surface. Next, the surface with the cylinder resting on it was inclined gradually using a screw device, until the box just started to slide down. The angle of tilt was read.

\section{Angle of Repose of Grain}

Angle of repose is the angle made by the inclined plane with the horizontal surface such that the body lying on the inclined plane is just at the verge of sliding down along the inclined plane. It is the measure of the maximum slope at which grains are stable. It is an important bulk property of the mung bean as it is required for the storage of the grains in piles and to design processing equipment and hoppers or conveyorbelt for transporting the grains from one part of a processing plant to another. It is measured by allowing bulk of grain to slide down from one side of the topless, bottomless box to make a heap at a certain angle. The angle made is measured as angle of repose. The reported values vary from 26 to $31^{\circ}$ with an average of $28^{\circ}$ (Nimkar and Chattopadhyay, 2001; Unal et al., 2008) at moisture contents ranging from 7.3 to $33.4 \% \mathrm{dw}$. The angle of repose was found to increase with an increase in the moisture content of the grain. Nimkar and Chattopadhyay (2001) reported that the angles of repose of mung bean are lower than those of pumpkin seeds and higher than those of chickpea.

\section{Rupture Strength of Grain}

Rupture strength is the minimum force applied to axial dimensions (length, width, and thickness) of the grain to deform it. Unal et al. (2008) reported that rupture strength is highly dependent on the moisture content and they indicated that greater forces were necessary to rupture seeds with lower moisture contents. The small rupturing force at higher moisture content is attributed to the fact that grain becomes more sensitive to cracking at high moisture content. Rupture strength of the grain has its importance during the development of mechanization of production processes for the preparation of, e.g., porridge, semolina, and split legume. The rupture strength of the mung bean was determined with a penetrometer at moisture contents ranging from 7.3 to $17.8 \%$.

\section{Projected Area of Grain}

The projected area of grain reflects its fluidization characteristics for which its front two-dimensional area is measured. It is important for the design and development of conveyers for transporting grains and agricultural machines. Unal et al. (2008) reported values for the projected area of 17.0 and $19.2 \mathrm{~mm}^{2}$ with an average of $18.4 \mathrm{~mm}^{2}$ in mung bean grains at moisture contents of $7.3-17.8 \% \mathrm{dw}$. The projected shape is globose, and reported to increase with an increase in moisture content. The projected area of the mung bean was determined by using a digital camera.

\section{B. CHEMICAL COMPOSITION}

The mung bean grain has three main parts, viz. testa, embryo, and cotyledons, which respectively constitute 12.2-23.5, 2.3, and 76.5-87.2\% dw of the whole grain (Singh et al., 1968; Muhammed et al., 2010). The chemical constituents are unevenly distributed in the different parts of the grain. The major chemical components of mung bean dry matter are carbohydrates, proteins, fat, fiber, ash, fatty acids, and amino acids, while micronutrients include minerals and vitamins. The minimum and maximum reported values along with calculated average value of each chemical constituent are given for each parameter in the respective tables. 
Table 2 Macronutrient composition of mung bean

\begin{tabular}{|c|c|c|c|c|}
\hline Macronutrient & Average* & Minimum & Maximum & References \\
\hline Crude protein $(\mathrm{g} / 100 \mathrm{~g}) \mathrm{dm}$ & 23.8 & 14.6 & 32.6 & $\begin{array}{l}\text { (Kadwe et al., 1974; Watson, 1977; Tsou and Hsu, 1978; Rao and } \\
\text { Belavady, 1979; Shehata and Thannoun, 1980; Rao and Deosthale, } \\
\text { 1983; Khader and Rao, 1986; Ignacimuthu and Babu, 1987; } \\
\text { Prabhavat, 1990; Poehlman, 1991; Singh and Singh, 1992; Sathe, } \\
\text { 1996; Jood et al., 1998; Bravo et al., 1999; El-Adawy et al., 2003; } \\
\text { Khatoon and Prakash, 2004; Mubarak, 2005; Fatima and Kapoor, } \\
\text { 2006; Barakoti and Bains, 2007; Khattak et al., 2007a, 2007b; } \\
\text { Mallillin et al., 2008) }\end{array}$ \\
\hline Crude lipid $(\mathrm{g} / 100 \mathrm{~g}) \mathrm{dm}$ & 1.22 & 0.71 & 1.85 & $\begin{array}{l}\text { (El-Adawy et al., 2003; Khatoon and Prakash, 2004; Mubarak, 2005; } \\
\text { Fatima and Kapoor, 2006; Barakoti and Bains, 2007; Watson, 1977; } \\
\text { Tsou and Hsu, 1978; Shehata and Thannoun, 1980; Prabhavat, } \\
\text { 1990; Poehlman, 1991; Singh and Singh, 1992; Sathe, 1996; Jood } \\
\text { et al., 1998; Bravo et al., 1999) }\end{array}$ \\
\hline Ash $(g / 100 g) d m$ & 3.51 & 0.17 & 5.87 & $\begin{array}{l}\text { (Tsou and Hsu, 1978; Shehata and Thannoun, 1980; Rao and } \\
\text { Deosthale, 1981; Rao and Deosthale, 1983; Prabhavat, 1990; } \\
\text { Poehlman, 1991; Sathe, 1996; Watson, 1977; Bravo et al., 1999; } \\
\text { El-Adawy et al., 2003; Khatoon and Prakash, 2004; Mubarak, 2005; } \\
\text { Fatima and Kapoor, 2006; Barakoti and Bains, 2007; Khattak et al., } \\
\text { 2007a) }\end{array}$ \\
\hline Carbohydrate $(\mathrm{g} / 100 \mathrm{~g}) \mathrm{dm}$ & 61.0 & 53.3 & 67.1 & $\begin{array}{l}\text { (Watson, 1977; Shehata and Thannoun, 1980; Prabhavat, 1990; } \\
\text { Poehlman, 1991; Singh and Singh, 1992; Sathe, 1996; El-Adawy } \\
\text { et al., 2003; Mubarak, 2005) }\end{array}$ \\
\hline Energy $(\mathrm{kcal} / 100 \mathrm{~g}) \mathrm{dm}$ & 344 & 338 & 347 & (Poehlman, 1991) \\
\hline
\end{tabular}

* Mean value of all collected data.

\section{Proximate Analysis}

The reported values for macronutrients are presented in Table 2. The crude protein content of mung bean shows large variations, which may be due to differences between varieties (Yohe and Poehlman, 1972; Thakare et al., 1988), different methods of analysis and growth conditions, as discussed later. Most authors used the micro-Kjeldahl method for analysis with a conversion factor of 6.25 to determine the protein content, whereas Cai et al. (2002) used the combustion method to extract nitrogen from their sample to nitrogen oxide, reducing it to nitrogen, which then is detected by a thermoconductivity detector. Most of the protein in mung bean is present in the cotyledons, with the majority of protein as salt-soluble storage globulins. Mung bean contains both storage proteins found in legume grains, viz. legumin and vicilin. Vicilin protein is glycosylated contrary to legumin globulin. Vicilin is more abundant in mung bean than legumin (Sathe, 1996). Vicilin is rich in acidic amino acids. Bhadra et al. (1991) reported a negative correlation between protein content and grain size; varieties with small-sized grains and a low yield were found to have a high protein content. However, Trung and Yoshipa (1983) reported a positive correlation between seed size and protein content $(r$ $=0.555)$. Research at the Asian Vegetable Research Development Centre (AVRDC) is based on crosses between large-seeded
Philippine and small-seeded Indian cultivars (Poehlman, 1991). Tomooka et al. (1992) distinguished eight protein types of mung bean varieties distributed over different geographical areas and, based on this, the authors suggested the origin of mung bean to be west Asia instead of India. Four proteins, named Vig r2 (52 kDa), Vig r3 (50 kDa), Vig r4 (30 kDa), and Vig r5 (18 kDa), in mung bean grains were reported to be potentially allergenic in nature as they induced strong IgE-mediated reactions (Misra et al., 2011). This is the only study on the potential allergic nature of proteins in mung bean and therefore further studies are required.

There is a wide variation in the reported lipid content that may be due to the genetic variation and/or different analytical methods. Most authors used soxhlet equipment and some Soxtec, which reduces the extraction time to two to three hours as compared to more than six hours for soxhlet equipment.

The average crude fiber content is $4.6 \mathrm{~g} / 100 \mathrm{~g} \mathrm{dw}$. Fiber content of mung bean is correlated with seed hardness due to the fact that hard seeds have a thick seed coat (Felicito and Evelyn Mae, 1990). The seed coat contains $12 \%$ more fiber than the cotyledons (Felicito and Evelyn Mae, 1990). Singh et al. (1968) reported that $80-93 \%$ of the crude fiber in mung bean is present in the seed coat, whereas the embryo contains only 2-3\% crude fiber. Apart from the reported maximum and minimum values, there is no wide variation in fiber content of 
mung bean. Most authors used the AOAC method to determine crude fiber, whereas El-Adawy et al. (2003), who reported the highest value of $6.2 \mathrm{~g} / 100 \mathrm{~g} \mathrm{dw}$, did not mention the method used.

Khattak et al. (2007b) reported the ash content of 13 varieties with an average value of $0.18 \mathrm{~g} / 100 \mathrm{~g} \mathrm{dw}$. This value is much lower than the average of the values from all other authors. The reason for this deviation is not known. In general, there is wide variation in the reported ash content, which may be partly genetic (Grewal and Jood, 2009). All authors used the AOAC method to determine the ash content.

The energy content of mung bean grains averages 344 $\mathrm{kcal} / 100 \mathrm{~g} \mathrm{dw}$. As the major energy components of mung bean are present in the cotyledons, removal of the seed coat and embryo during dehulling do not significantly reduce its energy value (Singh et al., 1968).

The variation in the reported values of the macronutrients is very large. This may be attributed to differences in detection methods and/or mung bean varieties. Most authors determined carbohydrates by difference. The number of authors who deter- mined macronutrients in mung bean is large compared to those who measured other parameters like nutrient digestibility and bioavailability.

\section{Carbohydrates}

Carbohydrates in mung bean (Table 3) have been analyzed by many authors; starch has been studied by most. Starch is used in noodle making in oriental countries (Cheng et al., 1988; Singh and Singh, 1992), except South Asian countries like India and Pakistan. Other carbohydrates in mung bean, including monosaccharides - maltose, glucose, xylose; oligosaccharides - raffinose, stachyose, verbascose; starch components - available and resistant starch; and fibers - lignin, cellulose, have been studied less frequently. There is wide variation in the carbohydrate fractions in mung bean, the reasons of which could be genetic makeup, or grain maturity. The amounts of maltose, xylose, arabinose, and inositol in mung bean were reported

Table 3 Carbohydrate profile of mung bean

\begin{tabular}{|c|c|c|c|c|}
\hline Carbohydrates $(\%)$ & Average* & Minimum & Maximum & References \\
\hline Glucose & 0.3 & 0.2 & 0.4 & (Udayasekhara Rao and Bhavani, 1978) \\
\hline Reducing sugars & 1.8 & 0.39 & 4.7 & (Kataria et al., 1988; Urooj and Puttaraj, 1994; El-Adawy et al., 2003) \\
\hline Nonreducing sugars & 6.3 & 4.9 & 8.1 & (Kuo et al., 1988; Kataria et al., 1988; Anisha and Prema, 2008) \\
\hline Raffinose & 1.1 & 0.3 & 2.6 & $\begin{array}{l}\text { (Iyengar and Kulkarni, 1977; Udayasekhara Rao and Bhavani, 1978; } \\
\text { Goel and Verma, 1981; Poehlman, 1991; Philip and Prema, 1998; } \\
\text { Bravo et al., 1999) }\end{array}$ \\
\hline Stachyose & 1.6 & 1.0 & 2.8 & $\begin{array}{l}\text { (Iyengar and Kulkarni, 1977; Goel and Verma, 1981; Adsule et al., } \\
\text { 1986; Kuo et al., 1988; Philip and Prema, 1998; Anisha and Prema, } \\
\text { 2008) }\end{array}$ \\
\hline \multicolumn{5}{|c|}{ Fibers } \\
\hline Total dietary fiber & 18.8 & 14.5 & 24.5 & (Veena et al., 1995; Khatoon and Prakash, 2006; Lin and Lai, 2006) \\
\hline Insoluble dietary fiber & 15.3 & 13.1 & 19.0 & $\begin{array}{l}\text { Rao, 2003) Khatoon and Prakash, 2006; Veena et al., 1995; Lin and } \\
\text { Lai, 2006) }\end{array}$ \\
\hline Soluble dietary fiber & 2.3 & 0.7 & 5.6 & $\begin{array}{l}\text { (Veena et al., 1995; Rao, 2003; Khatoon and Prakash, 2006; Lin and } \\
\text { Lai, 2006) }\end{array}$ \\
\hline Lignin & 3.9 & 2.2 & 7.2 & (Adsule et al., 1986; Rao, 2003) \\
\hline Cellulose & 3.9 & 2.5 & 4.6 & (Adsule et al., 1986; Rao, 2003) \\
\hline Hemi cellulose & 4.7 & 0.3 & 9.1 & (Adsule et al., 1986) \\
\hline \multicolumn{5}{|c|}{ Starch } \\
\hline Amylose & 24 & 14 & 35 & (Adsule et al., 1986) \\
\hline Starch & 47 & 37 & 58 & $\begin{array}{l}\text { (Aman, 1979; Adsule et al., 1986; Kataria et al., 1988; Kuo et al., } \\
\text { 1988; Prabhavat, 1990; Urooj and Puttaraj, 1994; Veena et al., 1995; } \\
\text { Sathe, 1996; Bravo et al., 1999; El-Adawy et al., 2003; Fatima and } \\
\text { Kapoor, 2006; Khatoon and Prakash, 2006) }\end{array}$ \\
\hline
\end{tabular}

* Mean value of all collected data. 
as $0.12,0.36,0.07$, and $0.04 \%$ of soluble sugars, respectively (Bravo et al., 1999).

Oligosaccharides, such as raffinose, stachyose, and verbascose, are associated with intestinal gas (flatus) production after consumption of beans (Iyengar and Kulkarni, 1977; Goel and Verma, 1981; Adsule et al., 1986; Kuo et al., 1988; Philip and Prema, 1998; Anisha and Prema, 2008). Flatulence is caused by such oligosaccharides that escape digestion and are fermented by the intestinal microflora. Mung beans contain less stachyose than red gram, lentils, and bengal gram. Fermentation was reported to reduce the flatulence factors in mung bean (Goel and Verma, 1981).

\section{Amino Acid Composition}

The highest values of amino acids in mung bean are reported for glutamic acid $(18.3 \mathrm{~g} / 16 \mathrm{~g}$ of $\mathrm{N})$ and aspartic acid $(12.9 \mathrm{~g} / 16 \mathrm{~g}$ N) (Table 4). Sekhon et al. (1980) reported a negative correlation of protein in mung bean with lysine and threonine, whereas a positive correlation of these amino acids with methionine has been found, suggesting that an increase in the methionine content in mung bean is always accompanied by a decrease of the total protein content in mung bean. Isoleucine, leucine, phenylalanine, tyrosine, and valine were found to be higher in the globulin fraction of the protein, whereas lysine, methionine, threonine, and tryptophan were higher in the albumin fraction (Bhatty, 1982).
Mubarak (2005) reported a chemical score of $76 \%$ for mung bean amino acids, which was calculated using the FAO/WHO (1973) reference pattern, whereas Tsou et al. (1979) reported that the chemical score of mung bean proteins is about $32 \%$ of egg protein (FAO, 1970) or $40 \%$ of the FAO provisional pattern. Mung bean grains are adequate in most essential amino acids with the exception of the sulfur-containing amino acids methionine and cystine, which can be compensated by consuming mung bean in combination with cereals. Cereals are rich in sulfur-containing amino acids and the deficiency of lysine in cereals gets compensated by its presence in mung bean. A 7:3 ration of rice protein to mung bean protein was suggested as good for consumption (Florentino, 1974). Geervani and Theophilus (1980) reported the availability of lysine, methionine, and cystine in mung bean grain to be 78,83 , and $94 \%$, respectively. Khan et al. (1979) reported a significant correlation $(r=0.97)$ between the biological value and the total amount of sulfur-containing amino acids in mung bean. This also indicates that from a nutritional point of view, it is advisable to consume mung bean in combination with foods high in sulfur-containing amino acids.

In general, wide variations exist in the reported values of the amino acid contents, which may be due to differences in the mung bean varieties used by the different authors, as different accessions of mung bean were reported to contain different amounts of the same amino acid, like lysine and methionine (Yohe and Poehlman, 1972). Another possible reason can be the analytical methods used by different authors. Cai et al. (2002) determined the cysteine and cystine contents of mung bean protein by analyzing the cysteic acid produced by oxidation of

Table 4 Amino acid composition of mung bean

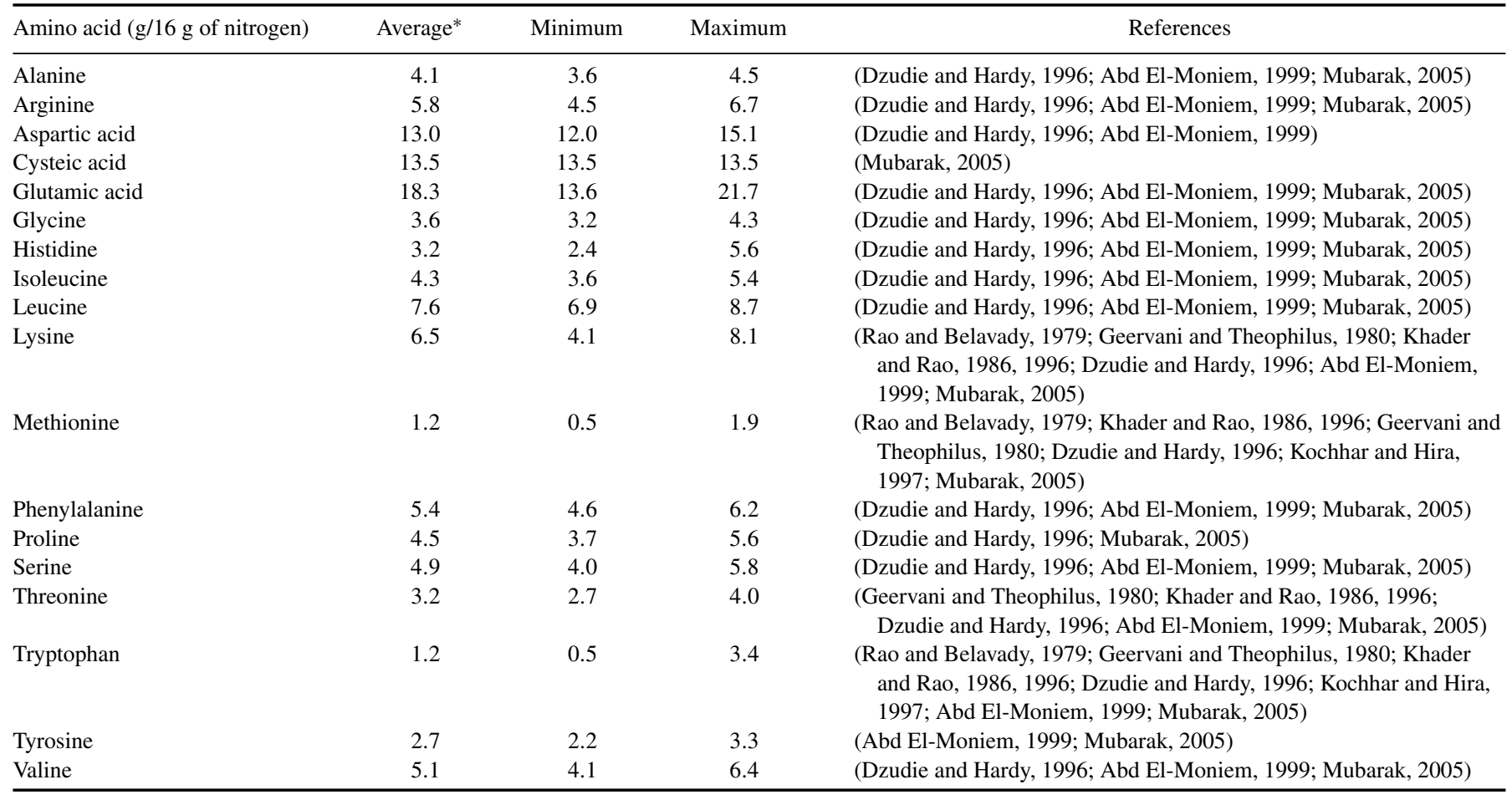

* Mean value of all collected data. 
Table 5 Lipid fraction of mung bean

\begin{tabular}{lcl}
\hline Lipid fraction & $\%$ of Total fat content & References \\
\hline $\begin{array}{l}\text { Total saturated fatty } \\
\quad \text { acids }\end{array}$ & 27.7 & (Sathe, 1996) \\
Total unsaturated fatty & 72.8 & \\
$\quad$ acid & & (Sathe, 1996) \\
C16:0 (Palmitic) & 14.1 & \\
C18:0 (Stearic) & 4.3 & (Sathe, 1996) \\
C18:1 (Oleic) & 20.8 & (Sathe, 1996) \\
C18:2 (Linoleic) & 16.3 & (Sathe, 1996) \\
C18:3 (Linolenic) & 35.7 & (Sathe, 1996) \\
C21 (Behenic acid) & 9.3 & (Sathe, 1996) \\
\hline
\end{tabular}

the cysteine and cystine. A microbiological assay was used by Vijayabaghavan and Srinivasan (1953) for most of the amino acids, but methionine was determined colorimetrically.

\section{Lipid Fraction}

Most lipid research on leguminous crops was on soya bean. Few investigations have dealt with the lipid fraction in mung bean (Table 5) and thus the information on the fatty acid composition of the mung bean is scanty. Lipids are components measured after saponification as compared to crude lipid, which is measured by a solvent extraction method like in, e.g., soxhlet. Adsule et al. (1986) reviewed the fatty acid composition of mung bean. The different fatty acids present in mung bean are palmitic, stearic, oleic, linoleic, linolenic, arachidic, behenic, capric, lauric, and myristic acid.

Abdel-Rahman et al. (2007) reported 33.1\% of total fat to be linoleic acid, which was higher than recorded by Adsule et al. (1986). Both authors reported that linoleic acid is the fatty acid that is present in the highest amount and that the quantity of lauric acid is the lowest in mung bean. The total amount of essential fatty acids in mung bean is reported to be $50.1 \%$ of total fat. Gopala Krishna et al. (1997) reported 35.6\% saturated fatty acids, 5.4\% monounsaturated fatty acids, $37.1 \%$ diunsaturated fatty acids, and $21.8 \%$ triunsaturated fatty acids in the oil extracted from the mung bean grain. Oil content of the mung bean is reported to vary from 2.1 to $2.7 \%$ (Zia-Ul-Haq et al., 2008). Reflective index, relative density, saponification value, iodine value, and unsaponifiable matter of the oil is found to be $1.5,1.0 \mathrm{~g} / \mathrm{cm}^{3}, 173-181 \mathrm{mg} \mathrm{KOH} / \mathrm{g}, 114-117$, and 13.8 to $15.0 \% \mathrm{w} / \mathrm{w}$, respectively (Zia-Ul-Haq et al., 2008).

Gopala Krishna et al. (1997) investigated the tocopherol and tocotrienol content of mung bean. The reported values for $\alpha$, $\beta$, and $\gamma$ tocopherol are $10.9,0.9$, and $1458 \mathrm{mg} / 100 \mathrm{~g}$ fat, respectively, while the values for $\alpha, \beta$, and $\gamma$ tocotrienol are $2.7,0.9$, and $1.9 \mathrm{mg} / 100 \mathrm{~g}$ fat, respectively. The total tocopherol content of mung bean $(12.5 \mathrm{mg} / 100 \mathrm{~g})$ is reported to be higher than in black gram $(6.7 \mathrm{mg} / 100 \mathrm{~g})$, bengal gram $(11.4 \mathrm{mg} / 100 \mathrm{~g})$, and horse gram $(7.4 \mathrm{mg} / 100 \mathrm{~g})$. The authors used a HPLC method to determine tocopherol isomers. There is no study for tocopherols and tocotrienol in mung beans.

Abdel-Rahman et al. (2007) reported the values of 32.3, 7.6, $6.6,5.7$, and $2.8 \%$ of lipid fraction for phospholipids, monoglycerides, 1, 2, and 2,3-diglycerides, sterols, and 1,3-diglycerides in mung bean, respectively. They also reported that the free fatty acid, hydrocarbons, sterols, and tri-glyceride fractions constitute $8.4,6.7,5.6$, and $30.1 \%$ of the lipid fraction in mung bean, respectively.

\section{Vitamins}

Vitamins reported in mung bean are thiamine, riboflavin, niacin, pantothenic acid, and nicotinic acid (Table 6). Vitamin $\mathrm{C}$ was reported to range from 0 to $10 \mathrm{mg} / 100 \mathrm{~g} \mathrm{dw}$ (Prabhavat, 1990) with an average of $3.1 \mathrm{mg} / 100 \mathrm{~g} \mathrm{dw}$. This variation could be due to experimental variation or genetic differences; the author does not provide an explanation. Barakoti and Bains (2007) reported $0.62 \mathrm{~g} / 100 \mathrm{~g}$ (fresh weight) ascorbic acid using the AOVC method (1996), whereas Kylen and McCready (1975) reported no ascorbic acid using the method involving extraction by $5 \%$ metaphosphoric acid in the bromine-oxidized filtrate by the 2,4 dinitrophenylhydrazine procedure. Apart from these three studies, all other reported values do not mention any underlying experimental research, thus more research needs to be done to assess the precise amount of ascorbic acid in raw mung bean. The number of authors who investigated the vitamin content is lower than the number of authors who determined macronutrients. Harina and Ramirez (1978) studied the carotenoid content of 20 mung bean varieties of different color and sizes and found that green colored mung bean grains

Table 6 Vitamin composition of mung bean

\begin{tabular}{|c|c|c|c|c|}
\hline Vitamin $(\mathrm{mg} / 100 \mathrm{~g}) \mathrm{dw}$ & Average* & Minimum & Maximum & References \\
\hline Thiamine & 0.5 & 0.12 & 0.7 & $\begin{array}{l}\text { (Kylen and McCready, 1975; Abdullah and Baldwin, 1984; Prabhavat, } \\
\text { 1990; Sathe, 1996; Ghavidel and Prakash, 2006) }\end{array}$ \\
\hline Riboflavin & 0.3 & 0.23 & 0.47 & $\begin{array}{l}\text { (Kylen and McCready, 1975; Abdullah and Baldwin, 1984; Prabhavat, } \\
\text { 1990; Sathe, 1996) }\end{array}$ \\
\hline Niacin & 2.2 & 1.1 & 3.1 & $\begin{array}{l}\text { (Kylen and McCready, 1975; Abdullah and Baldwin, 1984; Prabhavat, } \\
\text { 1990; Sathe, 1996) }\end{array}$ \\
\hline Vitamin C & 3.1 & 0 & 10 & (Prabhavat, 1990; Barakoti and Bains, 2007) \\
\hline Pantothenic acid & 1.9 & 1.9 & 1.9 & (Poehlman, 1991) \\
\hline Nicotinic acid & 1.6 & 1.6 & 1.6 & (Rao and Belavady, 1979) \\
\hline
\end{tabular}

*Mean value of all collected data. 
contained higher amounts of carotenoids $(0.9 \mathrm{mg} / 100 \mathrm{~g})$ than yellow varieties $(0.7 \mathrm{mg} / 100 \mathrm{~g})$, which is attributed to higher amounts of carotenoids in the seed coat of green colored varieties $(41.5 \%)$ than in that of yellow varieties (16.2\%) (Harina and Ramirez, 1978). These authors also found that the carotenoid content in cotyledons of mung bean $(0.5-0.8 \mathrm{mg} / 100 \mathrm{mg})$ differs slightly between green and yellow varieties, whereas it varies significantly in seed coats $(0.07-0.44 \mathrm{mg} / 100 \mathrm{mg})$ of green and yellow mung bean varieties. Carotenoids in mung bean are present in the form of $\beta$-carotene and xanthophylls (Harina and Ramirez, 1978). These authors also found that grain size has no correlation with the carotenoid content in mung bean. The riboflavin content of mung bean is found to be $0.29 \mathrm{mg} / 100 \mathrm{~g}$ (Nisha et al., 2005), which they assumed to be stable due to the protective effect of some unknown phytochemicals present. These authors also suggested further research on these phytochemicals and their protective effect on the riboflavin in mung bean. Degradation of riboflavin in mung bean during processing follows a first-order reaction at temperatures ranging from 50 to $120^{\circ} \mathrm{C}$ (Nisha et al., 2005). To our knowledge, there is no study on folic acid in mung bean.

\section{Minerals}

Minerals and trace elements are important for human health as they, for instance, play a significant role in the metabolism by acting as cofactor of enzymes. Mung bean contains a relatively high amount of minerals according to the literature reviewed (Table 7). The minerals in mung bean grains are calcium, copper, iron, potassium, magnesium, manganese, sodium, zinc, and other elements of nutritional importance like phosphorus, which is comparable to other pulses. Of these, iron, zinc, and calcium are the most important due to their physiological functions in the human body. Insufficient iron uptake is one of the most important factors for anemia throughout the world (Wang et al., 2008).

The total mineral content in mung bean grain is reported to be $3.5 \mathrm{~g} / 100 \mathrm{~g} \mathrm{dw}$ (Adsule et al., 1986). The cumulative mineral contents represent less than the total ash content; this is due to the fact that the minerals are determined as elements and the ash contains their salts. Ash may also contain salts of which the elements were not determined. Literature shows that mung bean contains considerable amounts of iron, calcium, and potassium. The amount of calcium in mung bean is four times higher than in cereals, but the amounts of calcium, iron, zinc, and phosphorus are lower than in soya bean. Singh et al. (1968) reported the distribution of different minerals in the anatomical parts of mung bean. They reported that calcium is primarily present in the seed coat (30-50\%, i.e., $(812 \mathrm{mg} / 100 \mathrm{~g} \mathrm{dw})$, iron in the embryo $(23 \mathrm{mg} / 100 \mathrm{~g} \mathrm{dw})$ and seed coat $(17 \mathrm{mg} / 100 \mathrm{~g}$ $\mathrm{dw})$, and phosphorus in the embryo $(756 \mathrm{mg} / 100 \mathrm{~g} \mathrm{dw})$ and cotyledons ( $341 \mathrm{mg} / 100 \mathrm{~g} \mathrm{dw})$. Removal of the embryo and seed coat during dehulling and milling will not affect the nutritive value of mung bean grain much (except for crude fiber and calcium), as these only account for a small proportion of whole mung bean grain (Singh et al., 1968).

Researchers used different methods to determine minerals, which might have contributed to the wide variation in the reported data. Rao and Deosthale (1981) used the AOAC (1960) method for calcium, phosphorous, and iron, whereas magnesium, zinc, manganese, copper, and chromium were analyzed using atomic absorption spectrometry. Barakoti and Bains (2007) also used atomic absorption spectrometry. Fatima and

Table 7 Mineral composition of mung bean

\begin{tabular}{|c|c|c|c|c|}
\hline Mineral $(\mathrm{mg} / 100 \mathrm{~g} \mathrm{dw})$ & Average* & Minimum & Maximum & References \\
\hline Copper & 1.0 & 0.9 & 1.5 & (Poehlman, 1991; Sathe, 1996) \\
\hline Iron & 5.9 & 4 & 7.6 & $\begin{array}{l}\text { (Kadwe et al., 1974; Rao and Deosthale, 1981; Narasinga Rao and Tatineni, } \\
\text { 1982; Rao and Deosthale, 1983; Hira et al., 1988; Poehlman, 1991; Sathe, } \\
\text { 1996; Chitra and Rao, 1997; Khatoon and Prakash, 2004; Lestienne et al., } \\
\text { 2005; Fatima and Kapoor, 2006; Fatima and Rashmi, 2006; Grewal and } \\
\text { Jood, 2006; Barakoti and Bains, 2007; Hemalatha et al., 2007b) }\end{array}$ \\
\hline Potassium & 956.6 & 326 & 1246 & (Watson, 1977; Prabhavat, 1990; Poehlman, 1991; Sathe, 1996) \\
\hline Magnesium & 162.4 & 50 & 320 & $\begin{array}{l}\text { (Kadwe et al., 1974; Tsou and Hsu, 1978; Rao and Deosthale, 1981; Rao and } \\
\text { Deosthale, 1983; Prabhavat, 1990; Poehlman, 1991; Sathe, 1996) }\end{array}$ \\
\hline Manganese & 1.05 & 1.0 & 1.1 & (Poehlman, 1991) \\
\hline Sodium & 16.7 & 6 & 30 & (Prabhavat, 1990; Sathe, 1996) \\
\hline Zinc & 2.7 & 2.4 & 3 & (Rao and Deosthale, 1983; Lestienne et al., 2005; Hemalatha et al., 2007b) \\
\hline
\end{tabular}

* Mean value of all collected data. 
Rashmi (2006) used AOAC (1995) methods, whereas Kadwe et al. (1974) used the EDTA titration method for calcium and magnesium. Khatoon and Prakash (2004) used the method of Ranganna (1986). Moreover, the variation in the mineral contents can also be due to genetic differences, which, among others, control the mechanism by which roots absorb minerals from the soil, and the translocation and physiological role of minerals in the plant as suggested by Frossard et al. (2000). This author also mentioned that mineral uptake mechanisms depend on root mycorrhiza and architecture, which may vary from variety to variety, causing variation in mineral contents.

Iron content has been studied the most in mung bean as compared to other minerals, probably due to its high significance for human health. After iron, calcium is the most studied mineral, followed by phosphorus.

Few authors have determined mineral bioavailability in mung bean. However, this is significant from a nutritional point of view. Reported values for the iron bioavailability in mung bean show wide variation, which may be due to different genetic factors (Chitra and Rao, 1997). Presence of minerals as such is of relative importance, as their actual absorption in the human body is affected by many factors that may be related to human physiology and/or the characteristics of the food itself. Among the food-related factors, presence of anti-nutritional components is most important. Literature shows that mineral bioavailability is affected by the presence of anti-nutritional factors like phytic acid, polyphenols as well as fiber (Canniatti Brazaca and Da Silva, 2003).

Mung bean varieties with high amounts of anti-nutritional factors cause a lower bioavailability of minerals (Grewal and Jood, 2006). The presence of relatively high amounts of phytic acid in mung bean is not only indicative of a low mineral bioavailability of divalent minerals like iron, zinc, and calcium but also of a low bioavailability of phosphorus, which was reported to be unavailable in young chickens (Common, 1939) as phosphorus in mung bean grain is mainly present in phytic acid. The wide variation in the reported mineral bioavailability may partly be due to the genetic basis (Jood et al., 1998). Minerals present in large amounts, like calcium, can also affect the iron and zinc bioavailability negatively. Variation in the amount of anti-nutrients (Kataria et al., 1989; Jood et al., 1998) and presence of endogenous phytase can also affect mineral bioavailability.

Increasing the mineral bioavailability in mung bean is possible by plant breeding, agricultural practices, and food processing techniques. Varieties can be developed with better abilities to acquire nutrients from the soil, and agronomic practices like fertilization influence the mineral content of the harvested seeds. Furthermore, it is possible to use breeding techniques to increase the concentration of nutrient-uptake enhancers, like ascorbic acid, and to decrease the concentration of nutrientuptake inhibitors like phytic acid, polyphenols, etc. (Frossard et al., 2000). Food processing techniques like fermentation and germination help in dephytinization (Barakoti and Bains, 2007; Hemalatha et al., 2007a). Processes like dehulling and cooking can reduce the amount of polyphenols, thereby increasing the nutritional value of the grain (Madhuri et al., 1996). Thus, increasing the iron content in mung bean will not be effective if anti-nutrients affecting its bioavailability are present in large quantities.

The term mineral bioavailability as used in the literature usually does not represent actual bioavailability in the human body, but signifies the in vitro mineral solubility assessed after treatment with digestive enzymes. To our knowledge, no study investigated the bioavailability of minerals from mung bean through the use of radioactive markers in humans. Molar ratios of phytic acid with minerals have been used as an indicator of their bioavailability (Adeyeye et al., 2000). In the case of mung bean, there is no literature available reporting these ratios.

\section{Anti-Nutritional Compounds}

Anti-nutritional factors (Table 8) are chemical compounds that negatively affect digestion, bioavailability, and bioconversion, and restrict the realization of the full nutritional potential of the food. Anti-nutritional components reported in mung bean are tannins, phytic acid, hemagglutinins, polyphenols, trypsin inhibitor, and proteinase inhibitor.

Phytic acid is the myo-inositol 1, 2, 3, 4, 5, 6, hexakisdihydrogen phosphate present in the crystalline form inside protein bodies in the cotyledons. It is negatively charged at

Table 8 Anti-nutritional factors in mung bean

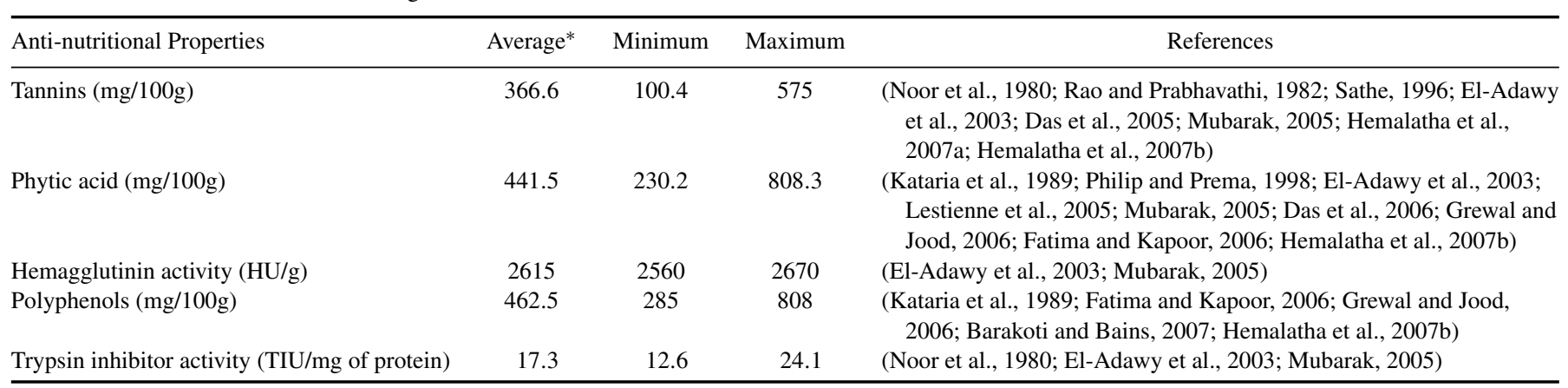

* Mean value of all collected data. 
physiological $\mathrm{pH}$, having a high affinity for positively charged divalent mineral ions making them unavailable for absorption. Phytic acid is the main seed storage molecule for phosphorus and is essential for seed development and germination. Phytates are compounds formed by the interaction of phytic acid with minerals. In legumes, phytates are present in the protein bodies of the endosperm. Wide variation exists in the reported values of phytic acid in mung bean, which may be due to genetic differences as there are reports suggesting a genetic basis of inheritance of phytate content in mung bean (Sompong et al., 2009). However, the variation could also be due to the method of analysis. Lestienne et al. (2005) determined phytate in mung bean by estimation of the myo-inositol hexaphosphate content obtained by anion exchange HPLC separation, whereas Grewal and Jood (2006) extracted phytic acid using 0.5 $\mathrm{M} \mathrm{HNO}_{3}$ and determined it colorimetrically. The reported value in mung bean is high enough to bind a significant amount of minerals, thus reducing their bioavailability. Based on the mean values presented in Tables 7 and 8 for iron and phytic acid, molar ratios of phytate/iron and phytate/zinc amount to 6.3 and 16.3, respectively, in raw mung bean. These values greatly exceed the cutoff values, viz. $<0.4$ and $<5$ respectively, regarded for adequate bioavailability (Nout, 2009). However, phytic acid can be reduced during cultivation and by food processing, which may improve this situation. However, the reduction of phytic acid during cultivation is not possible after a certain minimum limit as a further reduction hampers the physiological growth of the seedling (Bohn et al., 2008). Nutritionally, phytic acid can be considered an anti-nutritional compound but it provides resistance to the grain against the bruchid beetle Callosobruchus maculatus during storage (Srinivasan et al., 2007). Therefore, adequate food processing is important to degrade phytic acid (Coelho et al., 2002). Fermentation, germination, and dehulling are the food processing operations reported to effectively reduce the phytic acid content in mung bean (Barakoti and Bains, 2007; Hemalatha et al., 2007a).

Hemagglutinins are the sugar-binding proteins that bind with red blood cells and agglutinate them. They bind with specific receptors at epithelial cells of the intestine, causing lesions and improper microvillus development leading to abnormal absorption of nutrients. Only two authors (El-Adawy et al., 2003; Mubarak, 2005) investigated hemagglutinin activity in mung bean and they did not show much variation. The amount of hemagglutinin can be reduced by germination (El-Adawy et al., 2003). A high-temperature treatment during processing is reported to reduce hemagglutinins in red kidney beans (Thompson et al., 1983). The lectin content in mung bean is lower than in pea but higher than in lentils (El-Adawy et al., 2003).

Tannins are polyphenols that affect protein digestibility by making strong bonds with them, thus rendering them unavailable for absorption. The wide variation in the polyphenol content in mung bean could be due to genetic makeup (Dicko et al., 2002), type and amount of fertilization and the production site (Hamouz et al., 2006). Mung bean contains a considerable amount of polyphenols that affects the nutrient digestibility and bioavail- ability adversely. Therefore, efforts should be made to reduce the amount in mung bean grains. The possibilities for breeding seem promising in this respect, as polyphenols are reported to be present in higher amounts in colored and darker legume varieties than in pale varieties (Salunkhe et al., 1982). Thus, color of the mung bean can be used as a marker for the selection of varieties with lower amounts of polyphenols. Thus, products made of yellow or light colored mung bean varieties might have higher protein digestibility and mineral bioavailability, as polyphenols has been reported to reduce the protein digestibility and mineral bioavailability. Muhammed et al. (2010) suggested that, being bioactive molecules, the seed coat polyphenols can help the seed against pathogens and improve seed viability. Therefore, the yellow mung beans varieties may be cultivated for better yields. At food processing level, polyphenols can be reduced subsequently by using various processing methods. Polyphenols in mung bean have been reported to have a low protein precipitating capacity and relatively high flavanol contents (Barroga et al., 1985). These authors also reported that $81-85 \%$ of the polyphenols are present in the seed coat, which is three to four times more than in the cotyledon. Mung bean varieties contain $68-83 \mathrm{~g} / 100 \mathrm{~g}$ in the seed coat as compared to $17-32 \mathrm{~g} / 100 \mathrm{~g}$ in the cotyledon (Muhammed et al., 2010). The reduction in the polyphenol content due to dehulling ranged between $14 \%$ and 52\% (Muhammed et al., 2010). Nevertheless, even when $52 \%$ of polyphenols would be removed, the remaining concentrations (cf. Table 8) would still have a strong inhibitory effect on, e.g., iron bioavailability (Hurrell et al., 1999). This indicates that dehulling during dhal making is effective in reducing the polyphenol content of the food. Polyphenols are also reduced by roasting and leaching during soaking (Barroga et al., 1985).

Trypsin inhibitors inhibit proteolytic enzymes, thereby affecting protein digestion adversely. Trypsin inhibitor in mung bean does not inhibit chymotrypsin as well as vicilin peptidohydrolase (Chrispeels and Baumgartner, 1978). Trypsin inhibitor activity of mung bean is much lower than that of soya bean, kidney bean, and chickpea (Guillamón et al., 2008). Germination and soaking reportedly lower the trypsin inhibitor activity. Trypsin inhibitors are low molecular-weight proteins and thus likely to leach during soaking. Trypsin inhibitor activity is also reduced by heat treatments (Chandrashekar et al., 1989).

The presence of other anti-nutrients like proteinase inhibitors and sulfhydryl proteinase inhibitors in mung bean has not been reported. However, Marickar and Pattabiraman (1988) found a chymotrypsin inhibition of $427 \mu \mathrm{g} / \mathrm{g}$ in mung bean, indicating the presence of chymotrypsin inhibitors. To our knowledge, there is no published report on the presence of phytosterols, goitrogens, and toxicants such as phenolic glycosides, quinones, chromones, phynyl propanoids, anthrones, etc. in mung bean.

The presence of anti-nutritional factors in mung bean indicates that it is necessary to process the grain before consumption. The anti-nutritional factors can be partially removed or degraded by processing methods like fermentation, germination, and soaking, whereas a positive impact of mineral enhancers to increase mineral bioavailability has also been reported 
(Canniatti Brazaca and Da Silva, 2003). This can be one of the reasons why mung bean is consumed in the form of various food products, viz. snacks, sweets, and savory products.

\section{NUTRITIONAL PROPERTIES}

In vitro digestibility and bioavailability of nutrients are important properties, as they indicate the amount of the nutrient that is potentially absorbed by the human body. Digestibility and bioavailability are affected not only by other chemical components in the grain such as bioavailability enhancers like vitamin $\mathrm{C}$ in the case of iron but also by inhibitors of digestibility or bioavailability, such as phytic acid and polyphenols in the case of divalent minerals. Reports on in vitro protein digestibility show wide variation for mung bean (Table 9). In vitro protein digestibility is usually determined by measuring the change in the $\mathrm{pH}$ of the sample solution after incubation at $37^{\circ} \mathrm{C}$ with a trypsin - pancreatin enzyme mixture (Mertz et al., 1983). The wide variation in the protein digestibility can be due to the variation in the actual protein content as well as the presence of trypsin inhibitor, which has been reported to reduce the digestibility of protein. The protein digestibility of mung bean can be increased by thermal processing methods, which help in unfolding the protein structure and degrading anti-nutritional factors.

True digestibility of mung bean was reported to be $73 \%$ (Tsou and Hsu, 1978; Mubarak, 2005). Protein efficiency ratio of mung bean is 4.29 , which is quite high, whereas the essential amino acid index is 67.8. Rat-feeding experiments show that a combination of $75 \%$ protein from rice and $25 \%$ protein from mung bean gives a protein efficiency ratio equivalent to $75 \%$ of casein protein (Tsou and Hsu, 1978).

Net protein utilization of the food is the ratio of amino acid converted to proteins to the ratio of amino acids supplied. Its value ranges from 1 to 0 , with 1 meaning 100\% utilization of nitrogen present as protein, whereas 0 indicates no utilization. Tsou et al. (1979) reported that the biological value of mung bean could be improved by incorporating the high methionine character of black gram in mung bean through breeding as this character is not associated with a lower digestibility of proteins in black gram, and thus the desirable character of a high digestibility of mung bean will not be affected. The author also suggested that the amount of dipeptides present in mung bean also affects the biological value of its proteins. The dipeptides present in mung bean are $\gamma$-glutamyl-S-methylcystine and $\gamma$ glutamyl-S-methylcystine sulfoxide. The amount of the latter is smaller than that of the former compound (Otoul et al., 1975). This author also concluded that grains of mung bean were characterized by the presence of $\gamma$-glutamyl-S-methylcysteine and its sulfoxide, which makes it different from grains of urd bean (Vigna mungo), as the latter does not contain these compounds but is particularly rich in $\gamma$-glutamylmethionine and its sulfoxide.

\section{FOOD PROCESSING PROPERTIES}

The food processing properties of a raw food material determine its behavior during processing and thus affect the quality of the end product. The main food processing properties of significance for whole mung bean flour and grains are wettability, water and oil absorption capacity, gelation and emulsifying capacity, hydration capacity, hydration index, swelling capacity, swelling index, cooking time, and leached out solids (Table 10).

Water absorption capacity of mung bean flour is important since many products are prepared from flour dough and thus the quality of the final products is related to the water absorption capacity. The considerable variation in the data may be due to differences in chemical composition of the grains of different varieties. Most of the authors used centrifuge techniques for the determination of water absorption capacity. Its value has been reported to increase by germination and to decrease by dehulling (Ghavidel and Prakash, 2006).

Hydration capacity is the increase in weight of grains after absorption of water. Hydration capacity and hydration index are essential in producing sprouts, and thus high-quality sprouts are those possessing a high hydration capacity. Swelling capacity is the increase in the volume of the seed after absorption of water. Hydration and swelling capacity are the indicators of the potential of a grain to absorb water, thereby gaining weight

Table 9 Nutritional properties of mung bean

\begin{tabular}{|c|c|c|c|c|}
\hline Nutritional properties & Average* & Minimum & Maximum & References \\
\hline In vitro protein digestibility $(\%)$ & 70.2 & 52 & 83.9 & $\begin{array}{l}\text { (Singh and Padmakar, 1991; Hira et al., 1988; Mubarak, 2005; } \\
\text { Khatoon and Prakash, 2006) }\end{array}$ \\
\hline In vitro starch digestibility $(\mathrm{mg} / 100 \mathrm{mg}$ Maltose released) & 10.3 & 10.3 & 10.3 & (Khatoon and Prakash, 2004) \\
\hline Apparent digestibility & 65.4 & 65.4 & 65.4 & (Tsou and Hsu, 1978) \\
\hline True digestibility $(\%)$ & 49.2 & 25 & 73.3 & (Tsou and Hsu, 1978) \\
\hline Net protein utilization (NPU) & 56.3 & 53 & 59.7 & (Tsou and Hsu, 1978) \\
\hline Biological value $(\%)$ & 64.0 & 39 & 80.7 & $\begin{array}{l}\text { (Vijayabaghavan and Srinivasan, 1953; Tsou and Hsu, 1978; } \\
\text { Geervani and Theophilus, 1980; Poehlman, 1991; Rosaiah et al., } \\
\text { 1993; Sathe, 1996) }\end{array}$ \\
\hline Digestibility coefficient & 75.5 & 62 & 82 & (Geervani and Theophilus, 1980; Poehlman, 1991; Sathe, 1996) \\
\hline Chemical score $(\%)$ & 76.2 & 76.2 & 76.2 & (Mubarak, 2005) \\
\hline Essential amino acid index (\%) & 67.8 & 67.8 & 67.8 & (Mubarak, 2005) \\
\hline
\end{tabular}

*Mean value of all collected data. 
Table 10 Food processing properties of mung bean

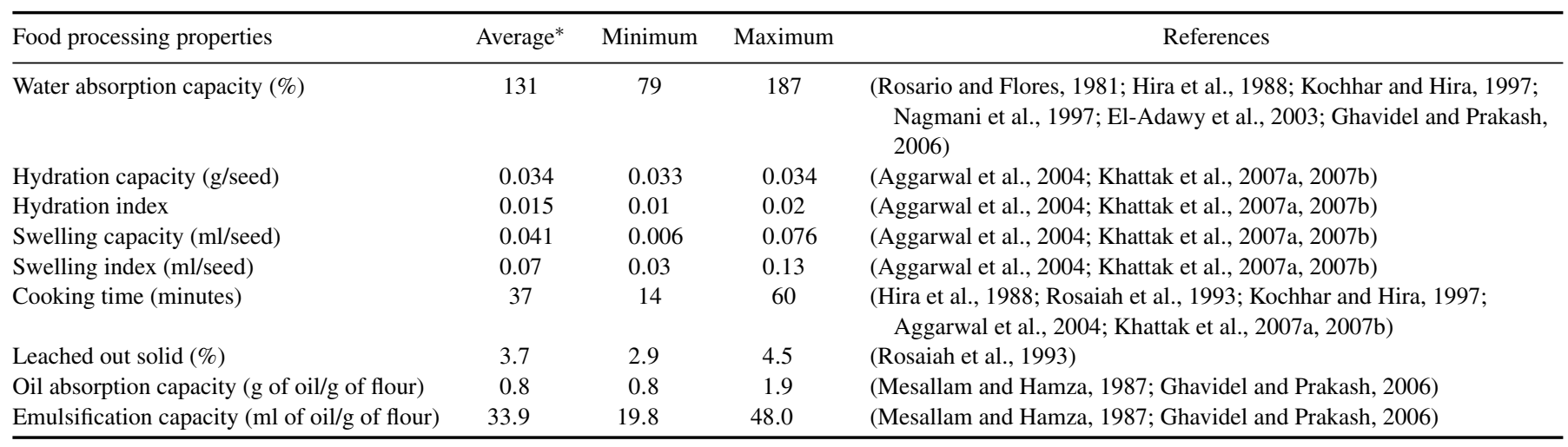

${ }^{*}$ Mean value of all collected data.

and volume. These parameters depend on the size of grains; Indian mung bean varieties with a small grain size will have lower hydration and swelling capacities than the large-sized varieties of south-east Asian countries. This may the reason for the production of large amounts of sprouts in Europe and in oriental countries, but not in India.

The gelation capacity of mung bean flour is important in products, which utilize oil for processing. The reported value of the gelation capacity of mung bean is contributed to the presence of protein (particularly the globulin fraction) and starch (Rosario and Flores, 1981). The authors used the least concentration endpoint method for determination of gelation capacity in mung bean. In this method, samples of different concentrations were stirred and adjusted to $\mathrm{pH} 7.0$ with $0.5 \mathrm{M} \mathrm{NaOH}$. Then, $10 \mathrm{ml}$ aliquots were heated for $10 \mathrm{~min}$ in an $80{ }^{\circ} \mathrm{C}$ water bath and cooled to $0{ }^{\circ} \mathrm{C}$ in an ice-bath. The strength of the coagulum was evaluated by inverting the tube. The lowest concentration of protein, which formed a stable gel or which remained inverted in the tube, was termed the gelation end-point.

Cooking time for mung bean grains varies from 14 (Khattak et al., 2007b) to 60 minutes (Aggarwal et al., 2004). The average cooking time is 37 minutes. The wide variation in the reported values is attributed to the fact that cooking time depends on the variety and the "hard-to-cook" phenomenon, which is related to storage conditions and duration of storage (Rodriguez and Mendoza, 1990). The influence of varietal differences on the amount of hard-to-cook seeds has been reported by Felicito and Evelyn Mae (1990). Cooking time might also depend on the chemical composition of the grain and seed coat. Thus, different varieties of mung bean with varying amounts of chemical constituents will have different cooking times. However, till now, no study has confirmed this correlation and thus it is necessary to determine the possible factors affecting the cooking time of mung bean grains.

Leached out solids during the cooking of grains determine the consistency and overall sensory acceptability of the products, particularly in soups and dhals. The average of reported values for the amount of leached out solids is $2.9 \%$ for different varieties (Rosaiah et al., 1993). The authors do not discuss the reported values but it seems likely that the amount of leached out solids is correlated with the rupture strength of the grains, as mung bean varieties with lower rupture strength tend to have lower amounts of leached out solids. Until now, no study has been conducted to confirm this supposition. Cooking time and temperature also influence the leached out solids and thus need to be studied.

Oil absorption capacity is relevant for mung bean as different products, particularly sweets and snacks, are prepared with mung bean flour as raw material and frying as processing method. Thus, it is important to use mung bean flour with a low oil absorption capacity to limit the fat content of the final product, which determines sensory characteristics as well as the shelf life. Oil absorption of whole mung bean flour has been studied, but oil absorption capacity of whole mung bean grain and dehulled mung bean grain is also important as these are used in making snacks. Therefore, oil absorption capacity of the mung bean grains and the effect of grain moisture and oil temperature on it should also be studied to optimize the frying of the mung bean grain to make snacks, like namkeen. Similarly, oil absorption of dehulled mung bean grain flour needs to be studied as mung bean laddo, an Indian sweet, is prepared from it with fat.

Emulsification capacity of whole mung bean flour is important for products that involve dough and batter making as important unit operations. Dzudie and Hardy (1996) reported the emulsification capacity of dehulled mung bean to be $21.7 \mathrm{ml}$ of oil/g of flour, which is higher than for dehulled red common bean $(19.8 \mathrm{ml}$ of oil/g of flour), black common bean $(14.5 \mathrm{ml}$ of oil/g of flour), and white common bean (15.5 ml of oil/g of flour). These authors suggested its appropriateness as an ingredient for meat analogs. Ghavidel and Prakash (2006) correlated emulsification capacity with the quality and quantity of soluble protein in mung bean and showed that during dehulling as soluble protein increases emulsification capacity also increases. Emulsification capacity of dehulled mung bean flour was found to be $73 \mathrm{ml}$ of oil/g of flour. Emulsification activity of whole mung bean flour is found to be $54 \%$, while its emulsification stability is $51.8 \%$ (Ghavidel and Prakash, 2006). Germination is reported to increase the emulsification activity in mung bean by 3\% and emulsification stability by 5\% (Ghavidel and Prakash, 
2006). These authors suggested that partial denaturation, increased hydrophobicity - to a certain extent, and increased protein solubility during germination might be the possible factors resulting in increased emulsification activity and stability in germinated mung bean flour as compared to non-germinated mung bean flour. Similarly, dehulling also increased emulsification activity and stability in mung bean, which is also suggested to be due to an increase in total and soluble protein content (Ghavidel and Prakash, 2006). High emulsification activity and stability of whole, dehulled, and germinated mung bean flours make them useful in food systems requiring stabilized colloidal emulsions (Ghavidel and Prakash, 2006). Emulsification capacity, activity, and stability should be determined for mung bean grains of different varieties so as to know their possible correlation with genetic makeup. Moreover, it will also help the characterization of mung bean varieties for their usefulness as meat analogs and in stabilized colloidal emulsions as proposed by several authors.

Information on food processing properties of mung bean flours is scarce. Certain food processing properties, like the $\mathrm{pH}$ of whole mung bean flour, have not been studied. It is important to know the $\mathrm{pH}$ of grain flour in a water suspension, since some food processing properties, such as solubility and emulsion properties, are highly affected by $\mathrm{pH}$ (McWatters and Cherry, 1977). Knowledge of food processing properties can help in new product development and mechanization of old traditional processes for the preparation of mung bean foods.

\section{CONCLUSION AND RECOMMENDATIONS}

The nutritional value of mung bean cannot be precisely evaluated from the data presented in literature to date. There are variations in the reported data, which might be due to a number of factors, but these factors have not been studied. Area of origin is one of the main factors contributing to the variation in values of different properties. Trung and Yoshida (1983) studied mung bean varieties from the Philippines and India and found that Philippine varieties are higher in protein content (23.4\%) and 1000 seed weight $(59.1 \mathrm{~g})$ than Indian varieties with an average $19.8 \%$ protein and a 1000 grain weight of $27.3 \mathrm{~g}$. The genetic makeup of the grain is one of the reasons for the variation in mung bean properties. Color of the grains is a function of genetic makeup of the variety and thus varies among varieties (Paroda and Thomas, 1988). Variations in properties were also noticed between wild and cultivated varieties. Cultivated mung bean varieties were found to posses higher amounts of certain amino acids like lysine, valine, isoleucine, leucine, phenylalanine, and tyrosine than wild varieties (Vigna radiata var. sublobata) in central India (Babu et al., 1988). The wide variation in the nutritional value also seems to be controlled by agronomical practices and location-to-location variations, which are insufficiently quantified. For example, phosphorus in the form of fertilizers is added for the proper growth of plants, but it has been reported that its use increases the phytate content of grains (Coelho et al., 2002).
Similarly, food processing properties need to be researched more and the effects of factors like temperature, $\mathrm{pH}$, and particle size on the variation in the reported data for different food processing properties. This variability in the reported values for different properties of mung bean may be due to raw material used for experimentation like quality of the sample, age of the sample, pretreatment given to the sample, etc. Physical and engineering properties of the grain are strongly affected by moisture content, which may vary in relation to the duration of storage after harvesting (Yildiz, 2005; Unal et al., 2008).

Storage conditions are reported to influence the food processing properties of the grain too. For example, cooking time increases with an increase in the storage period (Vimala and Pushpamma, 1985). The level of insect infestation during the storage of grains has also been reported to influence the chemical composition of the mung bean grains (Modgil and Mehta, 1994). Apart from the variability in the material, the analytical methods (sampling plans, sampling methods, analytical methods, and analytical quality control) can be another reason for the variability in reported values.

Our review shows that limited work has been carried out on the physical properties of mung bean and their relationship with moisture content. Nutritionally, mung bean seems to have a good potential with a higher protein content than chickpea, lower fat content than soya bean and a considerable amount of iron. The grain quality depends mainly on genetic factors, of which the expression is modified by agronomical practices. From the literature review on mung bean and its properties, it can be concluded that the reported information shows variations, although many investigations have been published about the nutritional properties of mung bean. There are gaps in the information on the different properties of the mung bean, which need to be filled as these play an important role in the nutritional potential of the grain and its processing behavior. The lack of information about some of the components, like vitamins and fatty acids, also persists. During future investigation of mung bean properties, care should be taken to control the experimental setup and limit the variability in sampling and analytical techniques. Data related to quality control during the various steps of analysis should be described in detail. Information on the type of sample used for analysis, like whole grain, dehulled or dehusked grain, should be clearly described; some authors, like (Elkowicz and Sosulski, 1982) failed to do this.

With respect to further research, we make the following recommendations:

1. Most mung bean breeding research has focused on yield, early maturation with uniform maturity and stable yield, resistance to pests, pathogens, and drought (Singh and Ahlawat, 2005). This needs to be expanded with nutritional and food processing properties.

2. More attention should be given to the appropriateness of analytical methods to be able to separate biological variation from analytical variation. Use of specific methods with good detection limits is advocated. 
3. Research on digestibility and bioavailability of nutrients in mung bean is needed as the factors that affect them are many and their behavior is not well understood.

4. Food processing properties need to be determined in greater detail, as literature on these parameters is limited.

5. Various properties of the dehusked mung bean dhal and dehulled mung bean dhal need to be determined as many products are made from them instead of whole mung bean grain, particularly in India.

6. The protein quality of mung bean needs to be improved by use of biotechnological and plant breeding techniques.

\section{REFERENCES}

Abd El-Moniem, G. M. (1999). Sensory evaluation and in vitro protein digestibility of mung bean as affected by cooking time. J. Sci. Food Agric. 79:2025-2028.

Abdel-Rahman, E. S. A., El-Fishawy, F. A., El-Geddawy, M. A., Kurz, T. and El-Rify, M. N. (2007). The changes in the lipid composition of mung bean seeds as affected by processing methods. Int. J. Food Eng. 3:1-10.

Abdullah, A. and Baldwin, R. E. (1984). Minerals and vitamins contents of seeds and sprouts of newly available small-seeded soybeans and market samples of mung beans. J. Food Sci. 49:656-657.

Adeyeye, E. I., Arogundade, L. A., Akintayo, E. T., Aisida, O. A. and Alao, P. A. (2000). Calcium, zinc and phytate interrelationships in some foods of major consumption in Nigeria. Food Chem. 71:435-441.

Adsule, R. N., Kadam, S. S., Salunkhe, D. K., Adsule, R. N., Kadam, S. S. and Salunkhe, D. K. (1986). Chemistry and technology of green gram (Vigna radiata [L.] Wilczek). Crit. Rev. Food Sci. Nutr. 25:73-105.

Aggarwal, V., Singh, N. and Kamboj, S.-S. (2004). Some properties of seeds and starches separated from mung (Phaseolus mungo) cultivars. J. Food Sci. Technol. 41:341-343.

Akhtar, M. I., Bhadra, S. K. and Quasem, A. (1988). Inheritance of seed-coat colour in mung bean (Vigna radiata (L.) Wilczek). Bangladesh J. Botany 17:111-116.

Aman, P. (1979). Carbohydrates in raw and germinated seeds from mung bean Phaseolus aureus and chick pea Cicer arietinum. J. Sci. Food Agric. 30:869-875.

Amirshahi, M. C. (1978). Mung bean: Breeding, production and utilization in Iran. In: Proceedings of the 1st International Mung Bean Symposium, pp. 233-235. Los Banos, Philippines.

Annapurani, S. and Murthy, N. K. (1985). Bioavailability of iron by invitro method II-from selected foods/diets and effect of processings. Indian J. of Nutr. Diet. 24:95-105.

Anisha, G. S. and Prema, P. (2008). Reduction of non-digestible oligosaccharides in horse gram and green gram flours using crude alpha-galactosidase from Streptomyces griseoloalbus. Food Chem. 106:1175-1179.

AOAC (1960). Official methods of analysis. 9th ed., p. 283. Association of Official Analytical Chemists, Washington, DC.

AOAC (1960). Official methods of analysis. 16th ed., Association of Official Analytical Chemists, Washington.

AOVC (1996). Methods of vitamin assays. Association of Vitamin Chemists, Inter Science Publishers, New York, pp. 306-312.

Babu, C. R., Sharma, S. K., Chatterjee, S. R. and Abrol, Y. P. (1988). Seed protein and amino acid composition of wild Vigna radiata var. sublobata (Fabaceae) and two cultigens Vigna mungo and Vigna radiata. Econ. Bot. 42:54-61.

Barakoti, L. and Bains, K. (2007). Effect of household processing on the in vitro bioavailability of iron in mung bean (Vigna radiata). Food Nutr. Bull. 28: $18-22$.

Barroga, C. F., Laurena, A. C. and Mendoza, E. M. T. (1985). Polyphenols in mung bean (Vigna radiata (L.) Wilczek) - Determination and removal. $J$. Agric. Food Chem. 33:1006-1009.
Baryeh, E. A. (2002). Physical properties of millet. J. Food Eng. 51:39-46. Bhadra, S. K., Akhter, M. I. and Quasem, A. (1991). Genetics of seed lustre and joint inheritance of seed-coat colour and seed lustre in mung bean (Vigna radiata (L.) Wilczek). Bangladesh J. Bot. 20:61-64.

Bhatty, R. S. (1982). Albumin proteins of eight edible grain legume species: Electrophoretic patterns and amino acid composition. J. Agric. Food Chem. 30:620-622.

Bohn, L., Meyer, A. S. and Rasmussen, S. K. (2008). Phytate: Impact on environment and human nutrition. A challenge for molecular breeding. J. Zhejiang Univ.: Sci. B. 9:165-191.

Bravo, L., Siddhuraju, P. and Saura-Calixto, F. (1999). Composition of underexploited Indian pulses: Comparison with common legumes. Food Chem. 64:185-192.

Cai, R., McCurdy, A. and Baik, B. K. (2002). Textural property of 6 legume curds in relation to their protein constituents. J. Food Sci. 67:1725-1730.

Canniatti Brazaca, S. G. and Da Silva, F. C. (2003). Enhancers and inhibitors of iron availability in legumes. Plant Food Hum. Nutr. 58:1-8.

Chandrashekar, S., Hunshal, S. and Malik, D. S. (1989). Effect of soaking and germination temperatures on selected nutrients and anti-nutrients of mung bean. Food Chem. 34:111-120.

Chen, H. and Liu, X. (2001). Inheritance of seed color and lustre in mungbean (Vigna radiata). Agric. Sci. Technol.- Hunan. 2:8-12.

Cheng, C., Tsou, S. C. S. and Wang, H. (1988). Utilization patterns of mung bean in the Chinese diet. In: Proceedings of the Second International Mung bean Symposium, pp. 498-507. Bangkok, Thailand, November 16-20, 1987.

Chhabra, A. K., Singh, V. P. and Kharb, R. P. S. (1990). Multifactor inheritance of seed coat in green gram (Vigna radiata (L.) Wilczek.). Euphytica. 47:153-158.

Chitra, U. and Rao, P. V. (1997). Effect of varieties and processing methods on the total and ionizable iron contents of grain legumes. J. Agric. Food Chem. 45:3859-3862.

Chrispeels, M. J. and Baumgartner, B. (1978). Trypsin inhibitor in mung bean cotyledons. Purification, characteristics, subcellular localization, and metabolism. Plant Physiol. 61:617-623.

Coelho, C. M. M., Santos, J. C. P., Tsai, S. M. and Vitorello, V. A. (2002). Seed phytate content and phosphorus uptake and distribution in dry bean genotypes. Br. J. Plant Physiol. 14:51-58.

Common, R. H. (1939). Phytic acid and mineral metabolism in poultry. Nature. 143:379-380

Das, P., Raghuramulu, N. and Chittemma Rao, K. (2006). Determination of bioavailable zinc from plant foods using in vitro techniques. J. Food Sci. Technol. 43:167-172.

Das, P., Raghuramulu, N. and Rao, K. C. (2005). Determination of in vitro availability of iron from common foods. J. Hum. Ecol. 18:13-20.

Devadas, R. P., Chandrasekhar, U., Vasanthamani, G. and Gayathri, V. (1977). Oligosaccharide levels of processed legumes. J. Food Sci. Technol., India. 14:5, 222-223. 10 references.

Dicko, M. H., Hilhorst, R., Gruppen, H., Traore, A. S., Laane, C., Van Berkel, W. J. H. and Voragen, A. G. J. (2002). Comparison of content in phenolic compounds, polyphenol oxidase, and peroxidase in grains of fifty sorghum varieties from Burkina Faso. J. Agric. Food Chem. 50:3780-3788.

Dzudie, T. and Hardy, J. (1996). Physico-chemical and functional properties of flours prepared from common beans and green mung beans. J. Agric. Food Chem. 44:3029-3032.

El-Adawy, T. A., Rahma, E. H., El-Bedawey, A. A. and El-Beltagy, A. E. (2003). Nutritional potential and functional properties of germinated mung bean, pea and lentil seeds. Plant Food Human Nutr. 58:1-13.

Elkowicz, K. and Sosulski, F. W. (1982). Antinutritive factors in eleven legumes and their air-classified protein and starch fractions. J. Food Sci. 47:13011304.

Engel, R. W. (1978). The importance of legumes as a protein source in Asian diets. In: Proceedings of the 1st International Mung Bean Symposium, pp. 35-39. Los Banos, Philippines.

FAO (1970). Amino-acid content of foods and biological data on proteins. FAO, Rome.

FAO/WHO (1973). Energy and protein requirements. Report of FAO Nutritional Meeting Series No 52. FAO, Rome. 
Fatima, S. and Kapoor, R. (2006). In vitro and in vivo glycemic effects of certain legumes. J. Food Sci. Technol. 43:263-266.

Fetima, S. and Raehmi, K. (2006). In vivo and in vitro glycemic effects of certain legumes. J. Food Sci. Technol. 43:263-266.

Rodriguez, F. M. and Mendoza, E. M. T. (1990). Physicochemical basis for hardseededness in mung bean (Vigna radiata (L.) Wilczek). J. Agric. Food Chem. 38:29-32.

Florentino, R. F. (1974). Nutritional aspects of eating rice. Philippine J. Nutr. 27:129-140.

Frossard, E., Bucher, M., Mächler, F., Mozafar, A. and Hurrell, R. (2000). Potential for increasing the content and bioavailability of $\mathrm{Fe}, \mathrm{Zn}$ and $\mathrm{Ca}$ in plants for human nutrition. J. Sci. Food Agr. 80:861-879.

Geervani, P. and Theophilus, F. (1980). Effect of home processing on the protein quality of selected legumes. J. Food Sci. 45:707-710.

Ghavidel, R. A. and Prakash, J. (2006). Effect of germination and dehulling on functional properties of legume flours. J. Sci. Food Agr. 86:1189-1195.

Goel, R. and Verma, J. (1981). Removal of flatulence factor of some pulses by microbial fermentation. Indian J. Nutr. Diet. 18:6, 215-217.

Gopala Krishna, A. G., Prabhakara, J. V. and Aitzetmüllerb, K. (1997). Tocopherol and fatty acid composition of some Indian pulses. J. Am. Oil Chem. Soc. 74:1603-1606.

Grewal, A. and Jood, S. (2006). Effect of processing treatments on nutritional and anti-nutritional contents of green gram. J. Food Biochem. 30:535-546.

Grewal, A. and Jood, S. (2009). Chemical composition and digestibility (in vitro) of green gram as affected by processing and cooking methods. Nutr. Food Sci. 39:342-349.

Guillamón, E., Pedrosa, M. M., Burbano, C., Cuadrado, C., Sánchez, M. d. C. and Muzquiz, M. (2008). The trypsin inhibitors present in seed of different grain legume species and cultivar. Food Chem. 107:68-74.

Hamouz, K., Lachman, J., Dvorak, P., Juzl, M. and Pivec, V. (2006). The effect of site conditions, variety and fertilization on the content of polyphenols in potato tubers. Plant, Soil and Environ. 52:407-412.

Harina, T. H. and Ramirez, D. A. (1978). The amount and distribution of carotenoids in the mung bean seed (Vigna radiata). Philippine J. Crop Sci. 3:65-70.

Hemalatha, S., Platel, K. and Srinivasan, K. (2007a). Influence of germination and fermentation on bioaccessibility of zinc and iron from food grains. Eur. J. Clin. Nutr. 61:342-348.

Hemalatha, S., Platel, K. and Srinivasan, K. (2007b). Zinc and iron contents and their bioaccessibility in cereals and pulses consumed in India. Food Chem. 102:1328-1336.

Hira, C. K., Kanwar, J. K., Gupta, N. and Kochhar, A. (1988). Cooking quality and nutritional evaluation of the rice-bean (Vigna umbellata). J. Food Sci. Technol. 25:133-136.

Humphry, M. E., Lambrides, C. J., Chapman, S. C., Aitken, E. A. B., Imrie, B. C., Lawn, R. J., McIntyre, C. L. and Liu, C. J. (2005). Relationships between hard seededness and seed weight in mung bean (Vigna radiata) assessed by QTL analysis. Plant Breeding. 124:292-298.

Hurrell, R. F., Reddy, M. and Cook, J. D. (1999). Inhibition of non-haem iron absorption in man by polyphenolic-containing beverages. Br. J. Nutr. 81:289-295.

Ignacimuthu, S. and Babu, C. R. (1987). Vigna radiata var. Sublobata (Fabaceae): Economically useful wild relative of urd and mung beans. Econ. Bot. 41:418-422.

Iyengar A. K. and Kulkarni P. R. (1977). Oligosaccharide levels of processed legumes. J. Food Sci. Technol. (India) 14:222-223.

Jood, S., Bishnoi, S. and Sehgal, S. (1998). Effect of processing on nutritional and anti-nutritional factors of moong bean cultivars. J. Food Biochem. 22:245-257.

Kadwe, R. S., Thakare, K. K. and Badhe, N. N. (1974). A note on the protein content and mineral composition of twenty-five varieties of pulses. Indian J. Nutr. Diet. 11:83-85.

Kataria, A., Chauhan, B. M., Kataria, A. and Chauhan, B. M. (1988). Contents and digestibility of carbohydrates of mung beans (Vigna radiata L.) as affected by domestic processing and cooking. Plant Food Human Nutr. 38:5159.
Kataria, A., Chauhan, B. M. and Punia, D. (1989). Anti-nutrients in amphidiploids (Black gram $\times$ Mung bean) - Varietal differences and effect of domestic processing and cooking. Plant Food Human Nutr. 39:257-266.

Katiyar, P. K., Chandra, S., Singh, B. B., Dixit, G. P. and Hasmat, A. (2007). Characterization of mung bean varieties released in India. Acta Horticul. 752:271-273.

Khader, V. and Rao, V. S. (1986). Effect of cooking and processing on protein quality of Bengal gram, green gram and horse gram. Indian J. Nutr. Diet. 23:57-65.

Khader, V. and Rao, S. V. (1996). Studies on protein quality of green gram (Phaseolus aureus). Plant Food Human Nutr. 49:127-132.

Khan, M. A., Jacobsen, I. and Eggum, B. O. (1979). Nutritive value of some improved varieties of legumes. J. Sci. Food Agr. 30:395-400.

Khatoon, N. and Prakash, J. (2004). Nutritional quality of microwave-cooked and pressure-cooked legumes. Int. J. Food Sci. Nutr. 55:441-448.

Khatoon, N. and Prakash, J. (2006). Nutrient retention in microwave cooked germinated legumes. Food Chem. 97:115-121.

Khattak, A. B., Bibi, N. and Aurangzeb (2007a). Quality assessments and consumers acceptability of the newly evolved mung bean genotypes. Am. J. Food Technol. 2:563-542.

Khattak, A. B., Nizakat, B. and Aurangzeb (2007b). Quality assessment and consumers acceptability studies of newly evolved mung bean genotypes ( $\mathrm{Vi}$ gna radiata). Am. J. Food Technol. 2:536-542.

Kochhar, A. and Hira, C. K. (1997). Nutritional and cooking evaluation of green gram (Vigna radiata. L. Wilczek) cultivars. J. Food Sci. Technol. 34:328-330.

Kuo, T. M., VanMiddlesworth, J. F. and Wolf, W. J. (1988). Content of raffinose oligosaccharides and sucrose in various plant seeds. J. Agric. Food Chem. 36:32-36.

Kylen, A. M. and McCready, R. M. (1975). Nutrients in seeds and sprouts of alfalfa, lentils, mung beans and soybeans. J. Food Sci. 40:1008-1009.

Lestienne, I., Icard-Verniere, C., Mouquet, C., Picq, C. and Treche, S. (2005). Effects of soaking whole cereal and legume seeds on iron, zinc and phytate contents. Food Chem. 89:421-425.

Lin, P.-Y. and Lai, H.-M. (2006). Bioactive compounds in legumes and their germinated products. J. Agric. Food Chem. 54:3807-3814.

Madhuri, K., Pratima, S. and Rao, B. Y. (1996). Effect of processing on in vitro carbohydrate digestibility of cereals and legumes. J. Food Sci. Technol. 33:493-497.

Mallillin, A. C., Trinidad, T. P., Raterta, R., Dagbay, K. and Loyola, A. S. (2008). Dietary fibre and fermentability characteristics of root crops and legumes. $B r$. J. Nutr. 100:485-488.

Mangaraj, S., Agrawal, S., Kulkarni, S. D. and Kapur, T. (2005). Studies on physical properties and effect of pre-millling treatments on cooking quality of pulses. J. Food Sci. Technol. 42:258-262.

Marickar, Y. and Pattabiraman, T. N. (1988). Changes in protease inhibitory activity in plant seeds on heat processing. J. Food Sci. Technol. 25:56-62.

McWatters, K. H. and Cherry, J. P. (1977). Emulsification, foaming and protein solubility properties of defatted soybean, peanut, field pea, and pecan flours. J. Food Sci. 42:1444-1450.

Mendoza, E. M. T., Barroga, C. F., Rodriguez, F. M., Revilleza, M. J. R. and Laurena, A. C. (1988). Factors affecting the nutritional quality and acceptability of mung bean (Vigna radiata (L.) Wilzeck). Trans. Nat. Acad. Sci. Technol. (Philippines) 10:305-322.

Mesallam, A. S. and Hamza, M. A. (1987). Studies on green gram (Phaseolus aureus) protein concentrate and flour. Plant Food Human Nutr. 37:17-27.

Mertz, E. T., Kirleis, A. W. and Axtell, J. D. (1983). In vitro digestibility of proteins in major food cereals. In: Federation Proceedings, Federation of American Societies for Experimental Biology, pp. 6026-6031.

Misra, A., Kumar, R., Mishra, V., Chaudhari, B. P., Raisuddin, S., Das, M. and DwivedI, P. D. (2011). Potential allergens of green gram (Vigna radiata L. Millsp) identified as members of cupin superfamily and seed albumin. Clin. Exp. Allergy. 41:1157-1168.

Modgil, R. and Mehta, U. (1994). Effects of different levels of Callosobruchus chinensis $L$. infestation on proximate principles, true protein, methionine and uric acid contents of greengram and redgram. J. Food Sci. Technol. 31:135-139. 
Molina, M. R., De La Fuente, G. and Bressani, R. (1974). Interrelationships between soaking time, cooking time, nutritive value and other characteristics of beans (Phaseolus vulgaris). J. Food Sci. 24:469-483.

Mubarak, A. E. (2005). Nutritional composition and anti-nutritional factors of mung bean seeds (Phaseolus aureus) as affected by some home traditional processes. Food Chem. 89:489-495.

Muhammed, T., Manohar, S. and Junna, L. (2010). Polyphenols of mung bean (Phaseolus aureus L.) cultivars differing in seed coat color: Effect of dehulling. J. New Seeds. 4:369-379.

Murakami, T., Siripin, S., Wadisirisuk, P., Boonkerd, N., Yoneyama, T., Yokoyama, T. and Imai, H. (1991). The nitrogen fixing ability of mung bean (Vigna radiata). In: Proceedings of the Mungbean Meeting, pp. 187-198. Chiang Mai, Thailand.

Nimkar, P. M. and Chattopadhyay, P. K. (2001). Some physical properties of green gram. J. Agric. Eng. Res. 80:183-189.

Nisha, P., Singhal, R. S. and Pandit, A. B. (2005). A study on degradation kinetics of riboflavin in green gram whole (Vigna radiata L.). Food Chem. 89:577-582.

Noor, M. I., Bressani, R. and Elias, L.G. (1980). Changes in chemical and selected biochemical components, protein quality and digestibility of mungbean (Vigna radiata) during germination and cooking. Plant Foods Human Nutr. 29:135-144.

Nout, M. J. R. (2009). Rich nutrition from the poorest - Cereal fermentations in Africa and Asia. Food Microbiol. 26:685-692.

Otoul, E., Marechal, R., Dardenne, G. and Desmedt, F. (1975). Sulphur dipeptides differentiate between Vigna radiata and Vigna mungo. Phytochem. 14:173-179.

Pandey, R. N., Pawar, S. E., Chintalwar, G. J. and Bhatia, C. R. (1989). Seed coat and hypocotyl pigments in green gram and blackgram. Proc. Ind. Acad. Sci. Plant Sci. 99:301-306.

Paroda, R. S. and Thomas, T. A. (1988). Genetic resources of mungbean (Vigna radiata (L.) Wilczek) in India. In: Proceedings of the Second International Symposium, pp. 19-28. Taipei, Taiwan.

Philip, J. and Prema, L. (1998). Oligosaccharides in cowpea (Vigna unguiculata) and green gram (Vigna radiata): varietal variation. Indian J. Nutr. Diet. 34:257-258.

Poehlman, J. M. (1991). The Mung Bean. 375 pp. Oxford and IBH Publishing Co., New Delhi.

Prabhavat, S. (1990). Mung bean utilization in Thailand. In: Proceedings of the Second International Symposium, pp. 9-15. Taipei, Taiwan.

Ranganna, S. (1986). Handbook of Analysis and Quality Control for Fruit and Vegetable Products. Tata McGraw-Hill, New Delhi.

Rao, B. N. (2003). Bioactive phytochemicals in Indian foods and their potential in health promotion and disease prevention. Asia Pacific J. Clin. Nutr. 12:9-22.

Rao, B.S.N. and Prabhavathi, T. (1982). Tannin content of foods commonly consumed in India and its influence on ionisable iron. J. Sci. Food Agr. 33:89-96.

Rao, D. S. S. and Deosthale, Y. G. (1981). Mineral composition of four Indian food legumes. J. Food Sci. 46:1962-1963.

Rao, P. K. and Deosthale, Y. G. (1983). Effect of germination and cooking on mineral composition of pulses. J. Food Sci. Technol. 20:195-197.

Rao, U. P. and Belavady, B. (1979). Chemical composition of high yielding verities of pulses varietal, locational and year to year differences. Indian $J$. Nutr. Diet. 16:440-446.

Rodriguez, F. M. and Mendoza, E. M. T. (1990). Physicochemical basis for hardseededness in mung bean (Vigna radiata (L.) Wilczek). J. Agric. Food Chem. 38:29-32.

Rosaiah, G., Santha Kumari, D., Satyanarayana, A., Rajarajeswari, V., Naidu, N. V. and Umaid, S. (1993). Cooking quality and nutritional characters of mung bean (Vigna radiata (L.) Wilczek) varieties. J. Food Sci. Technol. 30:219221.

Rosario, R. R. D. and Flores, D. M. (1981). Functional properties of flour types of mung bean flour. J. Sci. Food Agr. 32:175-180.

Rosario, R. R. d. (1991). Processing and utilization of legumes with particular reference to mung bean in the Philippines. In: Uses of Tropical Grain
Legumes: Proceedings of a Consultants Meeting, pp. 211-221. Patancheru, India.

Salunkhe, D. K., Jadhav, S. J., Kadam, S. S. and Chavan, J. K. (1982). Chemical, biochemical, and biological significance of polyphenols in cereals and legumes. Crit. Rev. Food Sci. Nutr. 17:277-305.

Sampath, S., Rao, M.-T., Reddy, K.-K., Arun, K. and Reddy, P. V. M. (2008). Effect of germination on oligosaccharides in cereals and pulses. J. Food Sci. Technol. 45:196-198.

Sathe, S. K. (1996). The nutritional value of selected asiantic pulses - chick pea, black gram, mung bean \& pigeon pea. In: Legumes and Oilseeds in Nutrition, pp. 12-32. Nwokolo, E. and Smart, J., Eds., Chapman and Hall, London.

Sekhon, K. S., Gupta, S. K. and Bakhshi, A. K. (1980). Amino acid composition of mung (Phaseolus aureus). Indian J. Nutr. Diet. 16:417-419.

Shehata, A. A. Y. and Thannoun, A. M. (1980). Chemical and amino acid composition of Iraqi mung beans. Zeitschrift fur Lebensmittel-Untersuchung und -Forschung. 171:360-362.

Singh, A. and Padmakar (1991). Effect of ultra violet radiation on nutritional quality of mung bean (Vigna radiata L.) seeds. Die Nahrung. 35:215-216.

Singh, D. P. and Ahlawat, I. P. S. (2005). Green gram (Vigna radiata) and blackgram (Vigna mungo) improvement in India: Past, present and future prospects. Indian J. Agr. Sci. 75:243-250.

Singh, S., Singh, H. D. and Sikka, K. C. (1968). Distribution of nutrients in the anatomical parts of common Indian pulses. Cereal Chem. 45:13-18.

Singh, U., Voraputhaporn, W., Rao, P. V. and Jambunathan, R. (1989). Physicochemical characteristics of pigeonpea and mung bean starches and their noodle quality. J. Food Sci. 54:1293-1297.

Singh, U. and Singh, B. (1992). Tropical grain legumes as important human foods. Econ. Bot. 46:310-321.

Singh, V. P., Chhabra, A. and Kharb, R. P. S. (1988). Production and utilization of mung bean in India. In: Second International Mung bean Symposium Proceedings, pp. 486-497. S. Shanmuga Sundaram, Ed., AVRDC, Shanhua, Tainan.

Sompong, U., Kaewprasit, C., Nakasathien, S. and Srinives, P. (2009). Inheritance of seed phytate in mung bean (Vigna radiata (L.) Wilczek). Euphytica. 171:389-396.

Sood, D. R., Wagle, D. S. and Dhindsa, K. S. (1982). Studies on the nutritional quality of some varieties of mung bean (Vigna radiata). J. Food Sci. Technol. 19:123-125.

Srinivasan, T., Duriaraj, C. and Senguttuvan, S. (2007). Role of phytic acid in the resistance of green gram (Vigna radiata (L.) Wilczek) seeds to Callosobruchus maculatus Fabricius (Bruchidae: Coleoptera). Pest Manage. Econ. Zool. 15:63-69.

Thakare, R. G., Gadgil, J. D. and Mitra, R. (1988). Origin and evolution of seed protein genes in Vigna mungo and Vigna radiata. In: Mungbean: Proceedings of the Second International Symposium, Asian Vegetable Research and Development Centre, pp. 47-52. Taipei, Taiwan.

Thompson, L. U., Rea, R. L. and Jenkins, D. J. A. (1983). Effect of heat processing on hemagglutinin activity in red kidney beans. J. Food Sci. 48:235-236.

Tomooka, N. (1991). Genetic diversity and landrace differentiation of mungbean, Vigna radiata (L.) Wilczek, and evaluation of its wild relatives (the subgenus Ceratotropis) as breeding materials. Tech. Bull. Trop. Agr. Res. Center (Japan). 28: 4-17.

Tomooka, N., Lairungreang, C., Nakeeraks, P., Egawa, Y. and Thavarasook, C. (1991). Center of genetic diversity, dissemination pathways and landrace differentiation in mung bean. In: Proceedings of the Mungbean Meeting 90, pp. 47-71. Chiang Mai, Thailand.

Tomooka, N., Lairungreang, C., Nakeeraks, P., Egawa, Y. and Thavarasook, C. (1992). Center of genetic diversity and dissemination pathways in mung bean deduced from seed protein electrophoresis. Theor. Appl. Genet. 83:289293.

Trung, B. C. and Yoshida, S. (1983). A comment on the varietal differences of production of mung bean and its grain properties. Soil Sci. Plant Nutr. 28:413-417.

Tsou, C. S., Hsu, M. S., Tan, S. T. and Park, H. G. (1979). The protein quality of mungbean and its improvement. Acta Hortic. 93:279-287. 
Tsou, S. C. S. and Hsu, M. S. (1978). The potential role of mung bean as a diet component in Asia. In: Proceedings of the 1st International Mung Bean Symposium, pp. 40-45. Cowell, R., Ed., AVRDC, Shanhua, Tainan, Taiwan.

Udayasekhara Rao, P. and Bhavani, B. (1978). Oligosaccharides in pulses: Varietal differences and effects of cooking and germination. J. Agric. Food Chem. 26(2):316-319.

Unal, H., Isik, E., Izli, N. and Tekin, Y. (2008). Geometric and mechanical properties of mung bean (Vigna radiata L.) grain: Effect of moisture. Int. J. Food Properties. 11:585-599.

Urooj, A. and Puttaraj, S. (1994). Effect of processing on starch digestibility in some legumes - an in vitro study. Nahrung-Food. 38:38-46.

Vavilov, N. I. (1926). Studies on the origin of cultivated plants. Bull. Appll. Bot. Genet. Plant Breeding. 16:1-248.

Veena, A., Ujooj, A. and Puttaraj, S. (1995). Effect of processing on the composition of dietary fibre and starch in some legumes. Nahrung. 39:132-138.

Vijayabaghavan, P. K. and Srinivasan, P. R. (1953). Essential amino acid composition of some common Indian pulses. J. Nutr. 51:261-271.

Vimala, V. and Pushpamma, P. (1985). Effect of improved storage methods on cookability of pulses stored for one year in different containers. J. Food Sci. Technol. 22:327-329.

Wang, B., Zhan, S. Y., Xia, Y. Y. and Lee, L. M. (2008). Effect of sodium iron ethylenediaminetetra-acetate (NaFeEDTA) on haemoglobin and serum ferritin in iron-deficient populations: A systematic review and metaanalysis of randomised and quasi-randomised controlled trials. Br. J. Nutr. 100:1169-1178.

Watson, J. D. (1977). Chemical composition of some less commonly used legumes in Ghana. Food Chem. 2:267-271.

Werker, E., Marbach, I. and Mayer, A. M. (1979). Relation between the anatomy of the testa, water permeability and the presence of phenolics in the genus Pisum. Ann. Bot. 43:765-771.

Yalcın, I. (2007). Physical properties of cow pea (Vigna sinensis L.) seed. J. Food Eng. 79:57-62.

Yalcın, I., Ozarslan, C. and Akbas, T. (2007). Physical properties of pea (Pisum sativum) seed. J. Food Eng. 79:731-735.

Yildiz, U. M. (2005). Some physical properties of mash bean seeds culivated in Turkey. S.U.Ziraat Fakultesi Dergisi. 35:41-45.

Yohe, J. M. and Poehlman, J. M. (1972). Genetic variability in the mung bean, Vigna radiata (L.) Wilczek. Crop. Sci. 12:461-464.

Yousif, A. M., Kato, J. and Deeth, H. C. (2003). Effect of storage time and conditions on the seed coat colour of Australian adzuki beans. Food Aust. 55:479-484.

Zia-Ul-Haq, M., Ahmad, M. and Iqbal, S. (2008). Characteristics of oil from seeds of 4 mung bean (Vigna radiata (L.) Wilczek) cultivars grown in Pakistan. J. Am. Oil Chem. Soc. 85:851-856. 